\title{
A UNIFIED TREATMENT OF HORIZONTAL DIRECT INVESTMENT, VERTICAL DIRECT INVESTMENT, AND THE PATTERN OF TRADE IN GOODS AND SERVICES
}

James R. Markusen Anthony J. Venables Denise Eby Konan Kevin H. Zhang

NBER Working Paper 5696

\section{NATIONAL BUREAU OF ECONOMIC RESEARCH 1050 Massachusetts Avenue Cambridge, MA 02138 \\ August 1996}

Markusen's portion of this research was financed under NSF grant SBR-9515219. This paper is part of NBER's research program in International Trade and Investment. Any opinions expressed are those of the authors and not those of the National Bureau of Economic Research.

(C) 1996 by James R. Markusen, Anthony J. Venables, Denise Eby Konan and Kevin H. Zhang. All rights reserved. Short sections of text, not to exceed two paragraphs, may be quoted without explicit permission provided that full credit, including $(\mathcal{C}$ notice, is given to the source. 


\title{
A UNIFIED TREATMENT OF HORIZONTAL DIRECT INVESTMENT, VERTICAL DIRECT INVESTMENT, AND THE PATTERN OF TRADE IN GOODS AND SERVICES
}

\begin{abstract}
This paper contributes to research endogenizing multinational firms in general-equilibrium trade models. We attempt to integrate separate contributions on horizontal multinationals which produce the same final product in multiple locations, with work on vertical multinationals, which geographically fragment production by stages. Previously derived results now emerge as special cases of a more general model. Vertical multinationals dominate when countries are very different in relative factor endowments. Horizontal multinationals dominate when the countries are similar in size and in relative endowments, and trade costs are moderate to high. In some cases, foreign investment or trade liberalization leads to a reversal in the direction of trade. Investment liberalization can also lead to an increase in the volume of trade and produces a strong tendency toward factor-price equalization. Thus direct investment can be a complement to trade in both a volume-of-trade sense and in a welfare sense.
\end{abstract}

James R. Markusen

Department of Economics

University of Colorado

Boulder, CO 80309-0256

and NBER

markusen@spot.colorado.edu

Denise Eby Konan

Department of Economics

University of Hawaii at Manoa

2424 Maile Way

Honolulu, HI 96822
Anthony J. Venables

London School of Economics

Houghton Street

London WC2A 2AE

UNITED KINGDOM

Kevin H. Zhang

Department of Economics

University of Colorado

Boulder, CO 80309 


\section{Introduction}

The theory of the multinational enterprise has traditionally been rather disjoint from the theory of international trade. International trade theory developed from a general-equilibrium tradition, usually relying on the twin assumptions of constant return to scale and perfect competition in production. The theory of the multinational enterprise has tended to be a branch of a more general theory of the firm, focussing on individual firms and their incentives to internally integrate activities across geographic space.

During the last fifteen years, the theory of international trade has broadened considerably, incorporating models based on increasing returns, imperfect competition, and in some case product differentiation. But the treatment of individual firms remains limited, generally detached both from the theory of the multinational enterprise and empirical evidence. Firms are modelled as single-plant, single-product organizations with all equity concentrated in the country of (single-plant) production. Yet industries with strong scale economies and oligopolistic market structures are often dominated by multinationals.

More recently, there have been attempts to endogenize multinational firms into generalequilibrium trade models. Firm-level characteristics combine with country-level characteristics and trade costs to determine what types of firms exist in equilibrium. Yet the various papers are limited in generality, in part due to severe technical challenges. Perhaps the most difficult of these is that characterizing the types of firms in existence as a function of parameter values is inherently an exercise in comparative statics on inequalities. Second, the dimensionality of even a minimal partialequilibrium model is large when their are alternative configurations of firms and plants.

Two branches of literature in particular remain separate. In one, multinationals are multiplant firms producing roughly the same product in different locations, substituting international production for trade (Markusen, 1984). These models of "horizontal" multinationals are particularly 
relevant empirically for investment among the developed economies. In the second branch, multinationals are firms that separate activities geographically with investment leading to intra-firm trade (Helpman, 1984). These models of "vertical" direct investment seem more relevant to investments into developing economies, a category which has been historically small but which has grown substantially during the last five years.

The purpose of this paper is to provide an integrated treatment of these models, so that various combinations of vertical multinationals, horizontal multinationals, and strictly national firms can arise endogenously as a function of parameter values. The parameters in question are trade costs, differences between countries in relative and in absolute factor endowments, and investment barriers. The horizontal model of Markusen, with generalizations by Horstmann and Markusen (1992), Brainard (1993), and Markusen and Venables (1995, 1996a,b) emerges as a special case as does the vertical model of Helpman, with extensions by Helpman and Krugman (1985), Konan (1996) and Zhang (1996).

The model begins in a traditional fashion with two countries, two goods, and two factors. One sector has increasing returns both at the firm (e.g., R\&D) and the plant level. Trade costs may exist between countries. The increasing-returns industry has six possible firm "types", with the types of firms active in equilibrium denoted a "production regime". There are two types of single-plant national firms (type-n firms), one for each country. These firm locate their "headquarters" activities in the same country as their single plant. Vertical multinationals (type-v firms) locate their headquarters and single plant in different countries as in Helpman's original model. Horizontal multinationals are two-plant firms, with their headquarters in one country. The two types each of vertical and horizontal multinationals are subscripted by country, in each case the country in which their headquarters activities are located. Headquarters activities (firm-level fixed costs) use only skilled labor, plant fixed costs use a combination of skilled and unskilled labor, and final production 
requires only unskilled labor. ${ }^{1}$

We show that vertical multinationals dominate production when the countries differ significantly in relative factor endowments, but are somewhat similar in size. Horizontal multinationals dominate when the countries are similar in both size and in relative endowments, and when trade costs are moderate to high. National firms dominate (a) when trade costs are low and relative endowments are similar or, (b) when trade costs are moderate, relative endowments are similar, and the countries differ significantly in size.

The "trade regime" (the direction of imports and exports), is of considerable interest in that it can differ substantially from standard Heckscher-Ohlin theory and its trade-industrial-organization extensions (e.g., Helpman and Krugman). While the increasing returns sector (X) is assumed skilledlabor intensive overall relative to the competitive sector $(\mathrm{Y})$, multinationals can unbundle this sector into separate activities, one of which is more skilled-labor intensive than $\mathrm{Y}$ (headquarters) and one of which is less skilled-labor intensive (final production). If differences in relative endowments are moderate, then the skilled-labor-abundant country exports X. But if the relative endowment difference is large, type-v firms enter, fragment the $\mathrm{X}$ sector, concentrating headquarters activities in the skilled-labor-abundant country and production in the unskilled-labor abundant country. This reverses the direction of trade, with the skilled-labor-abundant country importing $\mathrm{X}$.

The ratio of sales by affiliates of multinationals to the sum of trade flows and affiliate sales is of some interest. If trade costs are low, this ratio is highest when the countries differ significantly in relative endowment but are of similar size (type-v firms dominate). If trade costs are high, the ratio is highest when the countries are similar in both relative endowments and size (type-m firms

\footnotetext{
${ }^{1}$ Horizontal multinationals do have a vertical component to them, in that the headquarters services are supplied to the foreign branch plant. This is surely true of all multinationals: there are service flows within the firm. Our distinction between vertical multinationals and horizontal multinationals is in a sense simply one of definition. The form is a "vertical" relationship in the sense that services flow in one direction and final output in the other. There is no intra-firm trade in goods in the case of our horizontal firms.
} 
dominate).

We then inquire into the effects of multinationals by comparing an unrestricted equilibrium to one in which multinationals are banned by assumption. Results include the following. First, investment liberalization can, in some cases, reverse the direction of trade and/or increase the volume of trade. Second, investment liberalization (like trade liberalization in more traditional models) produces a strong tendency toward factor-price equalization. Thus direct investment and trade can be complements in both a volume-of-trade sense and in a welfare sense.

Throughout the paper, we will try to indicate the empirical relevance of certain situations and the potentially testable predictions generated by the model. 


\section{Model Structure}

The model has two countries ( $\mathrm{h}$ and $\mathrm{f}$ ) producing two homogeneous goods, $\mathrm{Y}$ and $\mathrm{X}$. There are two factors of production, $\mathrm{L}$ (unskilled labor), and $\mathrm{S}$ (skilled labor). $\mathrm{L}$ and $\mathrm{S}$ are mobile between industries but internationally immobile. Y will be used as numeraire throughout the paper. Skilled labor is used for the firm-specific fixed cost of producing $\mathrm{X}$, and plant-specific fixed costs use a combination of the two labor types. Unskilled labor is used in variable costs, and in addition there are transport costs between countries, specified as units of unskilled labor per unit of X exported.

Subscripts (i,j) will be used to denote the countries (f,h). The output of $Y$ in country $i$ is a CES function, identical in both countries. The production function for $\mathrm{Y}$ is

$$
Y_{i}=\left(a L_{i y}^{e}+(1-a) S_{i y}^{e}\right)^{1 / \varepsilon} \quad i=h, f
$$

where $\mathrm{L}_{\mathrm{iy}}$ and $\mathrm{S}_{\mathrm{iy}}$ are the unskilled and skilled labor used in the $\mathrm{Y}$ sector in country $\mathrm{i}$. The elasticity of substitution $(1 /(1-\epsilon))$ is set at 5.0 in the simulation runs reported later in the paper.

Superscripts (n,v,m) will be used to designate a variable as referring to national firms, vertical multinationals, and horizontal multinational firms respectively. $\left(\mathrm{m}_{\mathrm{i}}, \mathrm{v}_{\mathrm{i}}, \mathrm{n}_{\mathrm{i}}\right)$ will also be used to indicate the number of active $\mathrm{m}, \mathrm{v}$, and $\mathrm{n}$ firms based in country i. Hopefully, it will always be clear from the context what is being represented (e.g., $\mathrm{n}_{\mathrm{i}}$ as a variable in an equation always refers to the number of national firms in country i).

The quantification of fixed costs in the $\mathrm{X}$ sector is of considerable importance in this model. Notation is as follows, with F's denoting skilled-labor requirements and G's denoting unskilled-labor requirements.

$\mathrm{F}_{1}^{\mathrm{n}} \quad$ Skilled labor requirements of a type-n firm drawn from headquarters' country

$\mathrm{F}_{1}^{\mathrm{v}} \quad$ Skilled labor requirements of a type-v firm drawn from headquarters' country 
$\mathrm{F}_{1}^{\mathrm{m}} \quad$ Skilled labor requirements of a type-m firm drawn from headquarters' country

$\mathrm{F}_{2}^{\mathrm{v}} \quad$ Skilled labor requirements of a type-v firm drawn from non-headquarters' country

$\mathrm{F}_{2}^{\mathrm{m}} \quad$ Skilled labor requirements of a type-m firm drawn from non-headquarters' country

$G^{n} \quad$ Unskilled labor requirements for a type-n firm drawn from headquarters' country (where the plant is located).

$\mathrm{G}^{\mathrm{v}} \quad$ Unskilled labor requirements for a type-n firm drawn from the non-headquarters' country (where the plant is located).

$\mathrm{G}^{\mathrm{m}} \quad$ Unskilled labor requirements for a type-m firm, which must be incurred in each country (one $\mathrm{G}^{\mathrm{m}}$ for each plant).

Several assumptions guide us in specifying the relative values of fixed-cost parameters.

(a) Skilled labor need in fixed costs should be the same for both type-n and type-v singleplant firms $\left(F_{1}^{n}=F_{1}^{v}+F_{2}^{v}\right)$. But type-v firms will need to draw some of this skilled labor from the country in which the plant is located $\left(\mathrm{F}_{2}^{\mathrm{v}}>0\right)$. For type-n firms, all of these skilled labor requirements will be drawn from the headquarters' country.

(b) Skilled labor needed in fixed costs for type-m firms should be higher than the amount required for single-plant type-n and type-v firms, but much less than double the amount $\left(2 \mathrm{~F}_{1}^{\mathrm{n}}>\mathrm{F}_{1}^{\mathrm{m}}\right.$ $+\mathrm{F}_{2}^{\mathrm{m}}>\mathrm{F}_{1}^{\mathrm{m}}$ ). This latter assumption reflects the joint-input nature of knowledge capital. Type-m firms require somewhat more skilled labor in the headquarters' country $\left(F_{1}^{m}>F^{n}\right.$, reflecting technology-transfer and other costs) and some skilled labor in the host country. ${ }^{2}$

(c) Unskilled labor requirements should be the same for all plants and should be drawn entirely from the country in which a plant is located $\left(G^{m}=G^{n}=G^{v}\right)$.

(d) In order to prevent a degeneracy in the model and to account for the real possibility that

\footnotetext{
${ }^{2}$ Markusen and Venables (1995a,b) assume that all X-sector activities use factors in the same proportion or use just a single factor. Labor-market effects are only of second-order importance in those papers and not addressed. Assumptions similar to the present ones are introduced in Markusen and Venables 1995c, but there are no type-v firms. The technology-transfer cost $\left(\mathrm{F}_{1}^{\mathrm{m}}>\mathrm{F}_{1}^{\mathrm{n}}\right)$ is motivated by empirical results, especially those of Teece $(1977,1986)$, that direct investments require significant further investments in skilled-labor-intensive activities for multinational firms.
} 
there is some cost to separating plant and headquarters, we assume that all fixed costs for a type-v firm are $1 \%$ higher than the fixed costs for a type-n firm $\left(F_{1}^{v}+F_{2}^{v}=1.01 * F_{1}^{n}, G^{v}=1.01^{*} G^{n}\right) \cdot{ }^{3}$

Using these principles as guidelines, the values used in the simulations throughout the paper are as follows.

Nation Firms Headquartered in Country i:

$$
\mathrm{F}_{1}^{\mathrm{n}}=1.0 \quad \mathrm{G}^{\mathrm{n}}=1.0
$$

Horizontal Multinationals Headquartered in Country i:

$$
\mathrm{F}_{1}^{\mathrm{m}}=1.1 \quad \mathrm{~F}_{2}^{\mathrm{m}}=\mathbf{0 . 1} \quad \mathrm{G}^{\mathrm{m}}=1.0 \quad \text { (one } \mathrm{G}^{\mathrm{m}} \text { required for each plant) }
$$

Vertical Multinationals Headquartered in Country i:

$$
F_{1}^{v}=0.909 \quad F_{2}^{v}=0.101 \quad G^{v}=1.01
$$

Marginal factor requirements are constant in units of unskilled labor. ${ }^{4} \mathrm{X}_{\mathrm{ij}}^{\mathrm{n}}$ denotes the sales in country $j$ of a national firm based in country $i$. Let $w_{i}$, and $z_{i}$, denote the prices of unskilled labor and skilled labor respectively in country i. A national firm undertakes all its production in its base country, so the cost function of one national firm in country $i$ is given by

$$
w_{i} L_{i}^{n}+z_{i} S_{i}^{n}=w_{i}\left[c X_{i j}^{n}+(c+\tau) X_{i j}^{n}+G^{n}\right]+z_{i} F_{1}^{n}, \quad i, j=h, f, \quad i \neq j
$$

where $\mathrm{c}$ is the constant marginal production cost. $c, \mathrm{~F}_{1}^{\mathrm{n}}$, and $\mathrm{G}^{\mathrm{n}}$ are identical across countries. $\tau$ is the amount of unskilled labor needed to transport one unit of $X$ from country $i$ to country $j$, which

\footnotetext{
${ }^{3}$ Consider an equilibrium with at least one type- $\mathrm{n}_{h}$ firm and at least one type- $\mathrm{n}_{\mathrm{f}}$ firm. If we did not have this cost penalty these two firms could be exchanged for one type- $v_{h}$ firm and one type- $v_{f}$ firm and we would still have an equilibrium (total factor demands in each country are unchanged, etc.). Thus the equilibrium is degenerate. Our assumption of the $1 \%$ cost penalty seems very realistic, and avoids this technical problem.

${ }^{4}$ We assume that skilled workers cannot be used in X production (e.g., "unskilled workers" actually have manual/mechanical skills that cannot be used in $R \& D$, and vice versa for the skills of "skilled workers"). We could assume that skilled workers have the same productivity in $\mathrm{X}$ as unskilled workers, effectively binding the skilled-unskilled wage ratio to a lower bound of 1 . This would add 12 more inequalities to the model. In the parameterization we use, such a lower bound is almost never binding, except when multinationals are prohibited (used for comparison purposes), in which case the ratio is less than one in equilibrium in about $10 \%$ of the factor box.
} 
we assume to be the same in both directions. In our calibration, national firms in the $\mathrm{X}$ sector are moderately more skilled-labor intensive that Y-sector firms.

A horizontal multinational based in country $\mathrm{i}$ has sales in country $\mathrm{j}, \mathrm{X}_{\mathrm{i} j}^{\mathrm{m}}$. It operates one plant in each country incurring fixed costs, $\left(G^{m}, F_{1}^{m}\right)$ in its base country, and fixed costs $\left(G^{m}, F_{2}^{m}\right.$ ) in country $j$. Sales are met entirely from local production not trade. $L_{i j}^{m}\left(S_{i j}^{m}\right)$ denotes a country $i$ horizontal multinational firm's demand for unskilled (skilled) labor in country $j$. A firm type $m_{i}$ thus has a cost function

$$
w_{i} L_{i i}^{m}+w_{j} L_{i j}^{m}+z_{i} S_{i i}^{m}+z_{j} S_{i j}^{m}=w_{i}\left[c X_{i i}^{m}+G^{m}\right]+w_{j}\left[c X_{i j}^{m}+G^{m}\right]+z_{i} F_{1}^{m}+z_{j} F_{2}^{m} .
$$

Similarly, a vertical multinational based in country i (plant in country j) has sales in country $\mathrm{j}, \mathrm{X}_{\mathrm{ij}}^{\mathrm{v}} \cdot \mathbf{L}_{\mathrm{ij}}^{\mathrm{v}}\left(\mathrm{S}_{\mathrm{ij}}^{\mathrm{v}}\right)$ denotes a country i vertical multinational firm's demand for unskilled (skilled) labor in country j. A firm type $v_{i}$ has a cost function

$$
w_{j} L_{i j}^{v}+z_{i} S_{i i}^{v}+z_{j} S_{i j}^{v}=w_{j}\left[c X_{i j}^{m}+(c+\tau) X_{j i}^{v}+G^{m}\right]+z_{i} F_{1}^{v}+z_{j} F_{2}^{v}
$$

In our calibration, horizontal multinational firms are generally more skilled-labor intensive than national and vertical multinational firms, using more skilled labor for branch-plant fixed costs versus the additional unskilled labor for transport costs used by national or vertical firms. This depends, however, on firm scale.

Let $\overline{\mathrm{L}}_{\mathrm{i}}$ and $\overline{\mathrm{S}}_{\mathrm{i}}$ denote the total labor endowments of country $i$. Adding labor demand from $\mathrm{n}_{\mathrm{i}}$ national firms, $v_{i}$ and $v_{j}$ vertical multinationals, and $m_{i}$ and $m_{j}$ horizontal multinationals gives country i factor market clearing: 
(5)

$$
\begin{gathered}
\bar{L}_{i}=L_{i \mathrm{y}}+n_{i} L_{i}^{n}+m_{i} L_{i i}^{m}+m_{j} L_{j i}^{m}+v_{j} L_{j i}^{v} \\
\overline{S_{i}}=S_{i \mathrm{y}}+n_{i} S_{i}^{n}+m_{i} S_{i i}^{m}+m_{j} S_{j i}^{m}+v_{i} S_{i i}^{v}+v_{j} S_{j t}^{v}
\end{gathered}
$$

In equilibrium, the $X$ sector makes no profits so country $i$ income, denoted $M_{i}$, is

$$
M_{i}=w_{i} \bar{L}_{i}+v_{i} \bar{s}_{i} \quad i=h, f
$$

$p_{i}$ denotes the price of $X$ in country $i$, and $X_{i c}$ and $Y_{i c}$ denote the consumption of $X$ and $Y$. Utility of the representative consumer in each country is Cobb-Douglas,

$$
U_{i}=X_{i c}^{\alpha} Y_{i c}^{1-\alpha}, \quad X_{i c} \equiv n_{i} X_{i i}^{n}+n_{j} X_{j i}^{n}+m_{i} X_{i i}^{m}+m_{j} X_{j i}^{m}+v_{i} X_{i i}^{v}+v_{j} X_{j i}^{v}
$$

giving demands

$$
X_{i c}=\alpha M_{i} / p_{i}, \quad Y_{i c}=(1-\alpha) M_{i} .
$$

Equilibrium in the $\mathrm{X}$ sector is determined by pricing equations (marginal revenue equals marginal cost) and free-entry conditions. We denote proportional markups of price over marginal cost by $\mathrm{e}_{\mathrm{ij}}^{\mathrm{k}}$, $(k=n, m, v)$, so, for example, $\mathrm{e}_{\mathrm{j} i \mathrm{i}}^{\mathrm{m}}$ is the markup of a country $\mathrm{j}$ horizontal multinational in market i. Pricing equations of national, horizontal, and vertical firms in each market are (written in complementary-slackness form with associated variables in brackets):

$$
\begin{array}{ll}
p_{i}\left(1-e_{i i}^{n}\right) \leq w_{i} c & \left(X_{i i}^{n}\right) \\
p_{j}\left(1-e_{i j}^{n}\right) \leq w_{i}(c+\tau) & \left(X_{i j}^{n}\right) \\
p_{i}\left(1-e_{i i}^{m}\right) \leq w_{i} c & \left(X_{i i}^{m}\right) \\
p_{j}\left(1-e_{i j}^{m}\right) \leq w_{j} c & \left(X_{i j}^{m}\right)
\end{array}
$$




$$
\begin{array}{ll}
p_{i}\left(1-e_{j i}^{v}\right) \leq w_{i} c & \left(X_{j i}^{\nu}\right) \\
p_{i}\left(1-e_{i i}^{v}\right) \leq w_{j}(c+\tau) & \left(X_{i i}^{v}\right)
\end{array}
$$

In a Cournot model with homogeneous products, the optimal markup formula is given by the firm's market share divided by the Marshallian price elasticity of demand in that market. In our model, the price elasticity is one (see equation (8)), reducing the firm's markup to its market share. This gives, (also using demand equations (8)),

$$
e_{i j}^{k}=\frac{X_{i j}^{k}}{X_{j c}}=\frac{p_{j} X_{i j}^{k}}{\alpha M_{j}} \quad k=n, m, v \quad i, j=h, f
$$

There are six zero-profit conditions corresponding to the numbers of the four firm types. Given equations (9)-(14), zero profits can be written as the requirement that markup revenues equal fixed costs.

$$
\begin{aligned}
& p_{h} e_{h h}^{n} X_{h h}^{n}+p_{f} e_{h f}^{n} X_{h f}^{n} \leq w_{h} G^{n}+z_{h} F_{1}^{n} \\
& p_{f} e_{f f}^{n} X_{f f}^{n}+p_{h} e_{f h}^{n} X_{f h}^{n} \leq w_{f} G^{n}+z_{f} F_{1}^{n} \\
& p_{h} e_{h h}^{m} X_{h h}^{m}+p_{f} e_{h f}^{m} X_{h f}^{m} \leq w_{h} G^{m}+z_{h} F_{1}^{m}+w_{f} G^{m}+z_{f} F_{2}^{m} \\
& p_{f} e_{f f}^{m} X_{f f}^{m}+p_{h} e_{f h}^{m} X_{f h}^{m} \leq w_{f} G^{m}+z_{f} F_{1}^{m}+w_{h} G^{m}+z_{h} F_{2}^{m} \\
& p_{h} e_{h h}^{v} X_{h h}^{v}+p_{f} e_{h f}^{v} X_{h f}^{v} \leq w_{f} G^{v}+z_{h} F_{1}^{v}+z_{f} F_{2}^{v} \\
& p_{f} e_{f f}^{v} X_{f f}^{v}+p_{h} e_{f h}^{v} X_{f h}^{v} \leq w_{h} G^{v}+z_{f} F_{1}^{v}+z_{h} F_{2}^{v}
\end{aligned}
$$

To summarize the $\mathrm{X}$ sector in the model, the twelve inequalities (9)-(14) are associated with the twelve output levels (two each for six firm types), the twelve equations in (15) are associated with the twelve markups, and the six inequalities in (16)-(21) are associated with the number of firms of 
each type. Additionally goods prices are given by (8), income levels from (6) and factor prices from factor market clearing equation (5) together with labor demand from the $\mathrm{Y}$ sector.

The model is quite complex for two reasons. First, a bare-bones partial equilibrium version of the model would involve 30 non-linear inequalities as just noted. Second, it is a problem of comparative statics on inequalities, making traditional analytical, comparative-statics methods of limited value. The problems introduced by inequalities are compounded by the factor that we have five different production activities (Y, X-sector output, national-firm fixed costs, horizontal multinational-firm fixed costs, vertical multinational-firm fixed costs), all using factors in different proportions. $^{5}$

We did manage to make considerable analytical progress in two of our earlier papers, Markusen and Venables $(1995,1996 a, b)$. In the former we did this by examining a simplified partial equilibrium model (a model of the model) and in the latter by adopting a monopolistic-competition framework with fixed markup rules, and only three firm types. In both models, production and all fixed cost activities use factors in the same proportion and there are no vertical multinationals are permitted. In the next section, we will try to gain some intuition by reviewing analytical results from our earlier papers with appropriate extensions, and later in the paper simulate the full model which involves 51 non-linear inequalities using Rutherford's (1995) non-linear complementarity solver.

\footnotetext{
${ }^{5}$ Reviewing points made separately earlier, type-m firms are moderately more skilled-labor intensive than type-v firms which are moderately more skilled-labor intensive than national firms which are moderately more skilled-labor-intensive than $\mathrm{Y}$ production in our calibrations. But many of the interesting factor-market effects that we identify are driven by geographical rearrangement of activities when multinationals are allowed to enter rather than by the skilled-labor intensities of type-n or type-v firms versus type-m firms versus $\mathrm{Y}$ production per se.
} 


\section{General Discussion}

A brief review of our earlier separate results may be in order (Markusen and Venables, 1995, 1996a,b Konan, 1996, Zhang, 1996), along with some conjectures about how they will relate to one another in a more general model. First, consider the basic determinants of the production regime, defined as the set of firm types active in equilibrium. A basic feature of the model is that horizontal multinationals have multi-plant economies of scale, in that the total fixed costs for a two-plant firm are less than double the fixed costs for a one-plant firm. Given the parameterization of the model noted above, at the equilibrium factor prices prevailing in free trade the fixed costs of a type-m firm are about 1.52 times the fixed costs of a type-n or type-v firm. The latter are low fixed-cost organizations, but they must incur transport costs in serving a foreign market. The advantage of a type-v firm over a type-n firm in turn lies in the possibility of international differences in factor prices: large difference give the type-v firm an advantage in that it can locate each of its two activities in different countries according to factor-price differences. The broad determinants of the equilibrium production regime are as follows.

\section{Production Regime}

Type-m firms will tend to dominate when

Firm-level scale economies are high relative to plant-level scale economies

Total world demand is high

Trade costs are moderate to high

Countries are similar in relative factor endowments

Countries are similar in size.

Type-n firms will tend to dominate when

Trade costs are low and countries are similar in relative endowments and size

Trade costs are moderate and countries are very different in size.

Type-v firms will tend to dominate when

Trade costs are moderate to low, and countries differ significantly in relative endowments.

Some of this is fairly obvious, but a few comments about the roles of relative endowments and country sizes are appropriate. When trade barriers are moderate, type-m firms tend to have an 
advantage over type-n or type-v firm when the countries are similar in relative endowments and size. Neither country has an advantage in terms of a single plant, and the added fixed costs of having two plants outweighs the trade costs incurred by a one-plant firm. But if the countries are very different, then one of them has an advantage, either in terms of being a much larger market or in terms of having factor prices that favor $\mathrm{X}$ sector production. Single-plant firms located in this advantaged country then have an advantage over two-plant horizontal multinationals in that the latter must locate costly capacity in a small and/or high-cost market. Thus the association of horizontal multinationals with similar countries.

When single-plant firms dominate, the question of type-n firms versus type-v firms turns on factor-price equalization. If factor prices are roughly equalized with type-n firms dominating, then type-v firms cannot enter. There is a cost penalty to splitting headquarters and plant, and no offsetting advantage. When factor-prices are very different across the two countries, then there is an advantage in splitting the two activities, with the headquarters in country with cheap skilled labor and the plant in the country with cheap unskilled labor. Our conjecture is then that type-v firms should be able to enter when the two countries are very different in relative endowments so that factor prices are not equalized when only type-n firms produce. But differences in country sizes should not support type-v firms in equilibrium.

In the earlier work of Markusen and Venable, the comparison of horizontal multinationals with national firms suggested that multinationals tend to reduce the volume of trade in goods as exports of "producer services" (e.g., blueprints, managerial services) substitutes for trade in commodities. The addition of type-v firms make that less clear, as articles by Konan and Zhang show. Investment liberalization can lead to a reversal in the direction of trade as previously integrated firms, for example, begin to export component and producer services and re-import a large share of finished (assembled) products from a subsidiary in a smaller, unskilled-labor abundant country. Similar 
circumstance might lead to an increase in the volume of trade following trade liberalization.

Another possibility that investment liberalization can increase the volume of trade lies in the fact that, in the absence of multinationals, "comparative advantage" in $\mathrm{X}$ is determined by a combination of country size and relative endowment factors. The country relatively well endowed with skilled labor has a comparative advantage in $\mathrm{X}$, but the larger of two countries also has such a comparative advantage due to a "home market effect" familiar from the trade-industrial organization literature. When a country is large, but scarce in skilled labor it may export $\mathrm{X}$, but have a high price for skilled labor constraining its specialization and exports. The entry of type-v firms in such a situation basically relaxes this constraint by locating headquarters in the small, skilled-labor abundant country thereby leading to an increase in the volume of trade.

There is an interesting question about the volume of sales by affiliates of multinationals relative to trade, something that is amenable to empirical examination. Our model should predict that this ratio is high under the circumstance outline above so that horizontal multinationals dominate in equilibrium. But it may also be moderately high when vertical multinationals dominate in equilibrium. Unfortunately, this leads to a less-than-sharp prediction. If trade costs are high, then affiliate production relative to trade should be highest when the countries are similar in size and in relative endowments (type-m firms dominate). If trade costs are low, then affiliates should have a high share when the countries are very different in relative endowments (type-v firms dominate). These conjectures are summarized as follows.

\section{Trade Regime}

The entry of multinationals (removal of an investment ban) may reverse the direction of trade in $\mathrm{X}$ when the countries differ significantly in relative endowments.

The entry of multinationals may increase the volume of trade when one country is larger but is relative well endowed with unskilled labor. 
The ratio of affiliate sales to the volume of trade plus affiliate sales is high when (a) trade costs are low and the countries differ significantly in relative size, (b) trade barriers are moderate to high and the countries are similar in both relative endowments and size.

Finally, there are interesting questions concerning how multinationals affect factor prices, a subject we addressed in Markusen and Venables, 1996a. We noted that the entry of horizontal multinationals generated a tendency toward international factor-price equalization in almost all cases. Those results should be reinforced here with the addition of vertical multinationals. As noted above, type-v firms in this model are creatures of situations where factor prices are unequal in their absence. Allowing direct investment leads firms to fragment and rearrange $\mathrm{X}$-sector activities, putting more $\mathrm{R} \& \mathrm{D}$ in the skilled-labor-abundant country and more production in the unskilled-labor-abundant country, thus moving the world toward factor-price equalization.

\section{Factor-Price Equalization}

The removal of investment barriers should generate a strong tendency toward factor-price equalization. 


\section{Production Regimes}

Figure 1 shows simulation results for three alternative values of transport costs, $\tau=.00, .05$, and .10. Each panel is an Edgeworth box with the total world endowment of unskilled labor on the horizontal axis and the total world endowment of skilled labor on the vertical axis. The origin for country $h$ is at the southwest corner and the origin for country $f$ at the northeast corner. These diagrams will be familiar to most readers from the work of Dixit and Norman (1980) and the adaptations to industrial-organization models by Helpman and Krugman (1985).

In the parameterization we use, the skilled-unskilled wage rate at the center point of the factor box is very steep; although this wage ratio is about 1.48 though the center, there are actually many more units of unskilled labor than skilled labor, so that geometrically the factor-price ratio is very steep. The point of mentioning this is that country size effects are very important in this model in some cases, and in effect country $h$ is smaller (in total income) at all points left of column 10 and larger at all points to the right of column 10 in all of the diagrams.

The top panel of Figure 1 shows a simplified regime diagram for the case of free trade (complete characterizations are provided in an appendix). There is a central region in which only national firms operate, flanked by areas in which there is a mixture of type-n and type-v firms. In the northwest corner only type-v $\left(v_{h}\right)$ firms are active in equilibrium and similarly an area of only type-v $\left(v_{f}\right)$ firms in the southeast corner. Obviously, these are regions in which only the unskilledlabor-abundant country produces $\mathrm{X}$ while all headquarters are located in the skilled-labor abundant country. ${ }^{6}$

Results here are reminiscent of Helpman (1984). As the countries become very different in relative endowments, factor-price equalization fails to hold in the absence of multinationals, creating

\footnotetext{
${ }^{6}$ We might note that, because of the assumed cost penalty, type- $v_{h}$ and type- $v_{f}$ firms can never co-exist. One each of these firms could be displace by one each of a type- $n_{h}$ and type- $n_{f}$ firms. The latter generate exactly the same outputs and factor demands except for having a $1 \%$ lower fixed cost.
} 
an opportunity for type-v firms to enter. The middle panel of Figure 1 shows similar results, with a quantitative difference in that the region in which only national firms are active shrinks.

The bottom panel of Figure 1 with $\tau=.10$ provides an integrated case that cannot be found in previous writings (Zhang, 1996) suggests this in a partial-equilibrium model. All six firm types exist in some region of the factor box (again, see the appendix for a complete characterization). In the central region, type-m firms exist; only type-m firms exist in the core of this region while the outer edges are generally a mixture of type-m and type-n firms. Horizontal multinationals exist when the countries are relatively similar in size and in relative factor endowments, a point emphasized by Markusen and Venables $(1995,1996 a, b){ }^{7}$

As the countries become increasing different in relative factor endowments, factor prices become unequal, creating an opportunity for type-v firms to enter in the manner we have already discussed. When countries differ in relative endowments but are also very different in size, there is a mixture of national and multinational firms (relevant to all three panels).

For example, near the lower left-hand edge of all three panels, types $n_{f}$ and $v_{h}$ firms exist in equilibrium (see appendix). Country h is relatively well endowed with skilled labor making it suitable for headquarters activities, but it is too small to support all such activity. Thus type $n_{f}$ firms exist as well. All final production occurs in the large, unskilled-labor-abundant country. This case may be relevant to some small, but skilled-labor abundant countries such as Sweden, Switzerland, and The Netherlands. These countries are home to many multinationals, but much of their production occurs abroad.

Zhang (1996) notes an interesting hypothesis that follows from these results: as a developing country begins to catch up in both size and in relative endowments, we might see it first attract

\footnotetext{
${ }^{7}$ Horizontal multinationals do not exist in the Helpman model because of the assumption of zero trade costs throughout. Vertical multinationals are not considered in the original Markusen model and in the Markusen and Venables papers.
} 
vertical investment, and later horizontal investment to service the local market. He maintains that this process is indeed going on in China. 
Figure 1: Simplified Regime Diagrams with Transport Costs $\tau=.00, .05, .10$
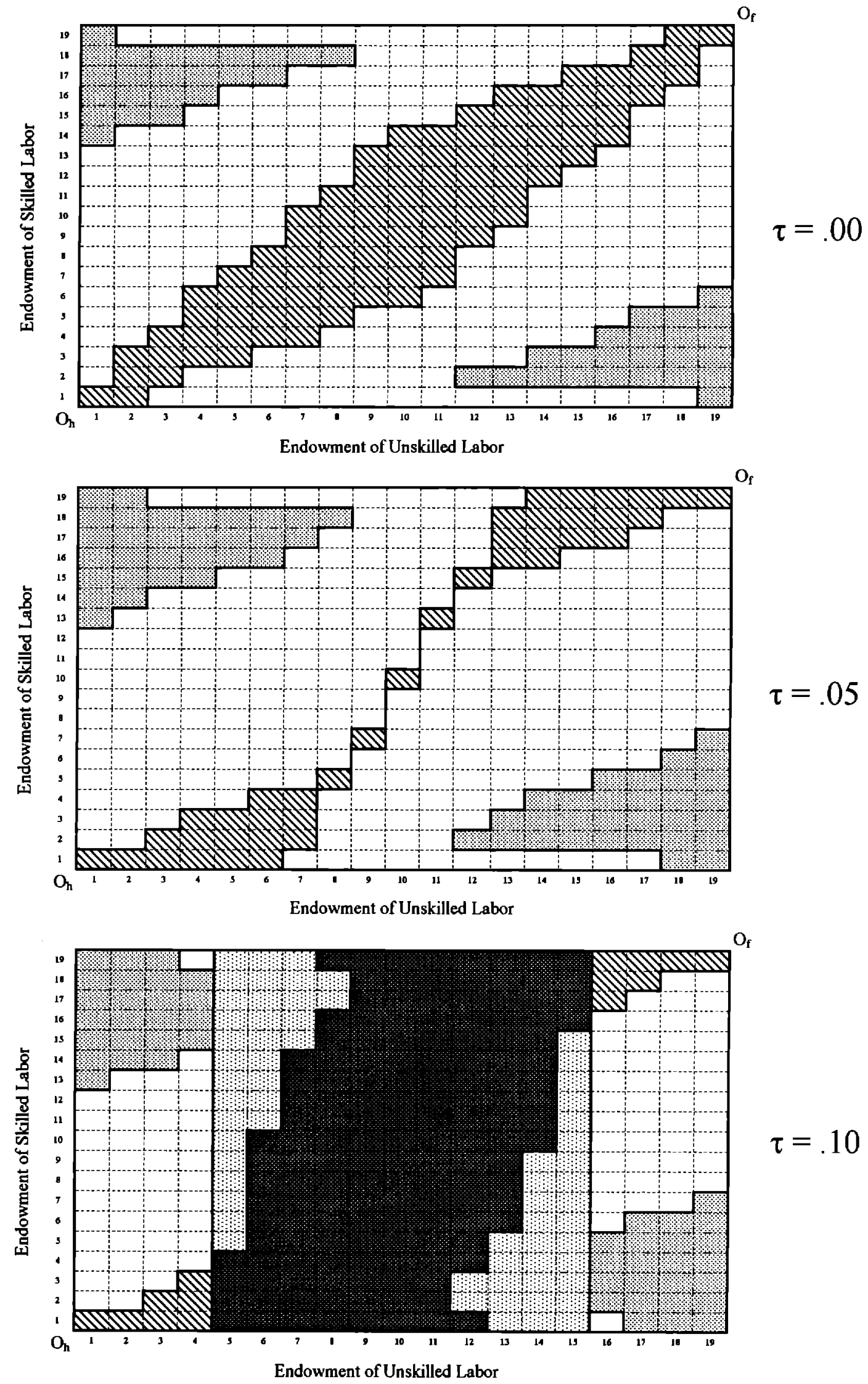

Type v firms only

Type $v$ firms exist, no type $m$ firms

Type $n$ firms only

Type $m$ firms exist, no type $v$ firms

Other mixed regimes 


\section{Trade Regimes}

Figure 2 shows the equilibrium trade regimes for transport costs $\tau=.00, .05$, and .10 in the three panels corresponding to Figure 1. By "exports of S", we are referring to services of skilled labor embodied in the headquarters services supplied to foreign plants by multinationals (skilled labor in not itself internationally mobile). Thus there are two traded goods in the model, $\mathrm{X}$ and $\mathrm{Y}$, and a traded service. If for example only type- $\mathrm{v}_{\mathrm{h}}$ firms existed in equilibrium, then these firm are providing headquarters services to country $f$ in exchange for markup revenues which would likely be repatriated in terms of X. Country h might either import or export $\mathrm{Y}$, but statistics would show a net deficit for country $\mathrm{h}$ in trade in goods only, the balancing item being the "invisible" service flow to foreign plants.

The top panel of Figure 2 (costless or free trade) shows that country h exports $\mathrm{X}$ for points above, but not too far above the diagonal. This follows from the fact that the $\mathrm{X}$ sector overall is skilled-labor-intensive relative to the $Y$ sector. But when the difference in relative endowments becomes large, factor-price equalization fails to hold and it becomes profitable for type- $\mathrm{v}_{\mathrm{h}}$ firms to enter. These firms unbundle the X-sector activities into headquarters services (more skilled-laborintensive than Y) and final production (less skilled-labor-intensive than Y). In the northwest corner area of Figure 2, country $\mathrm{h}$ then exports $\mathrm{Y}$ and $\mathrm{S}$, and imports $\mathrm{X}$.

The large unshaded region to the northwest of the center point in the middle panel in which country $h$ imports $X$ and exports $S$ and $Y$ requires some explanation (types $v_{h}$ and $n_{f}$ firms are active in equilibrium over most of this region). Some point in this region actually lie below the diagonal. Driving this result is a country size effect, which will appear several times in our results. Two effects drive "comparative advantage" in this model as we noted earlier: relative endowments and country size. Due to the scale economies in $\mathrm{X}$ and the nature of markup determination, location in the larger market is advantageous for a firm in the presence of trade costs, because most of the firm's sales are in its low-cost market. In the absence of multinationals, the larger country will be the headquarters 
country for most national firms (out of proportion to country size differences) and be the exporter of $\mathrm{X}$ along the SW-NE diagonal of the factor box. But since the relative endowments of the two countries are the same, this must in turn imply that the relative price of skilled labor is higher in the large country. That in turn implies that if multinationals are permitted, type-v firms headquartered in the small country will enter in equilibrium.

The bottom panel of Figure 2 adds a central region in which there is no trade in $\mathrm{X}$ (all $\mathrm{X}$ is produced by type-m firms), with peripheral regions in which one country imports both $\mathrm{X}$ and $\mathrm{Y}$ in exchange for exports of services. For example, in cell row 17 and column 8 in the lower panel, type $v_{h}$ and $m_{h}$ firms exist in equilibrium (see appendix). All firms are headquartered in $h$ and a very high service export volume is matched by imports of both $\mathrm{X}$ and $\mathrm{Y}$.

Some recent empirical evidence suggests that the volume of direct investment in the world economy has been growing faster than the volume of trade, especially among the developed countries, over the last two decades. There has been a large increase in the flow of direct investment from developed to developing countries over the las five years, although the stock of direct investment in developing countries remains fairly small.

Figure 3 considers the volume of sales by foreign affiliates of type-m and type-n firms divided by that amount plus the total volume of trade in $\mathrm{X}$ and $\mathrm{Y} .{ }^{8}$ It takes on a value of zero when there are only type-n firms in existence and may have a value of one when there are only type-m firms. ${ }^{9}$ When trade costs are low or zero, the statistic is small or zero near the center of the factor box and when the countries differ in size but not in relative endowments (type-n firms dominate in these

\footnotetext{
${ }^{8}$ There are several alternative statistics which could be used. One is to consider only arm's length trade in $\mathrm{X}$ in the denominator, so that for example $\mathrm{X}$ export by type- $\mathrm{v}_{\mathrm{h}}$ firms from the plant in $\mathrm{f}$ to $\mathrm{h}$ are not counted. We found no strong reason to prefer one statistic over another.

${ }^{9}$ Having only type-m firms is not sufficient for a value of one. If more of these firms are headquartered in one country, that country will be a net exporter of $S$ and a net importer of $Y$. Thus some commodity trade still occurs in equilibrium.
} 
areas). But it can take on values in the $.30-50$ range when the countries are significantly different in relative endowments but similar in size (type-v firms dominate). Once again, this is the result of unequal factor prices in spite of free trade that create opportunities for type-v firms.

As trade costs become higher in the bottom panel of Figure 3, the central region changes very substantially with horizontal multinational firms replacing national firms. The statistic at and near the center in fact jumps from zero to one. Now the affiliate sales ratio is highest when the countries are similar in both size and in relative endowments. But it remains moderately high when the countries are very different in relative endowments but similar in size, and near zero when the countries are very different in size. This gives us some sharp empirical predictions, but unfortunately the affiliate sales ratio between very similar countries is greatly sensitive to the level of trade costs. 
Figure 2: Trade Regime Diagrams with Transport Costs $\tau=.00, .05, .10$
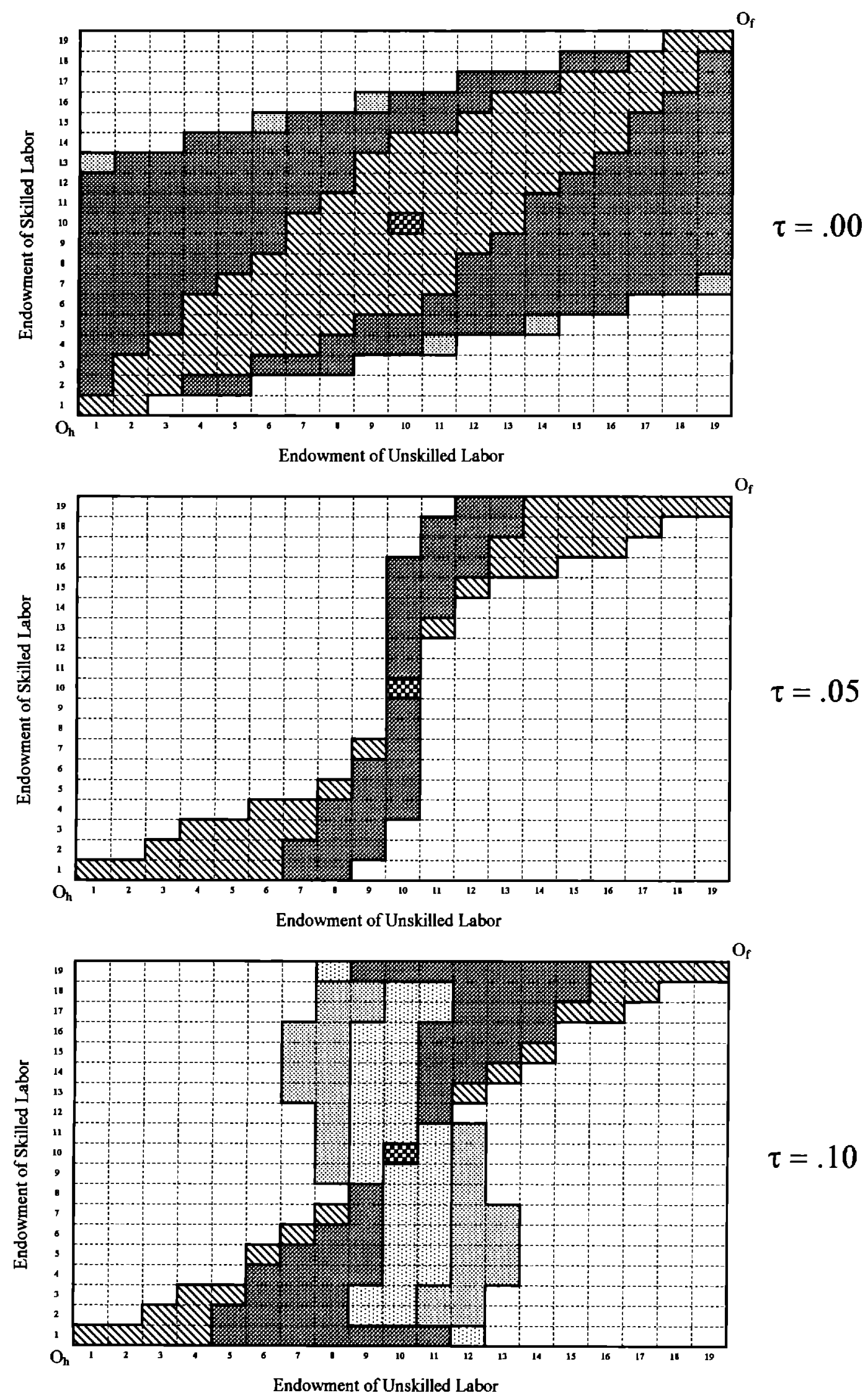

Above Diagonal, Country h:

Exports Y, Imports X, Exports S

Imports $Y$, Exports $X$

Imports $Y$, Exports $X$, Exports $S$

Imports $Y$, Imports $X$, Exports $S$

Imports $Y$, Exports $S$
Below Diagonal, Country h: Imports $Y$, Exports $X$, Imports $S$ Exports $Y$, Imports $X$ Exports $Y$, Imports $X$, Imports $S$ Exports $Y$, Exports $X$, Imports $S$ Exports $Y$, Imports $S$ 
Figure 3: Volume of Affliate Sales Relative to the Volume of Trade
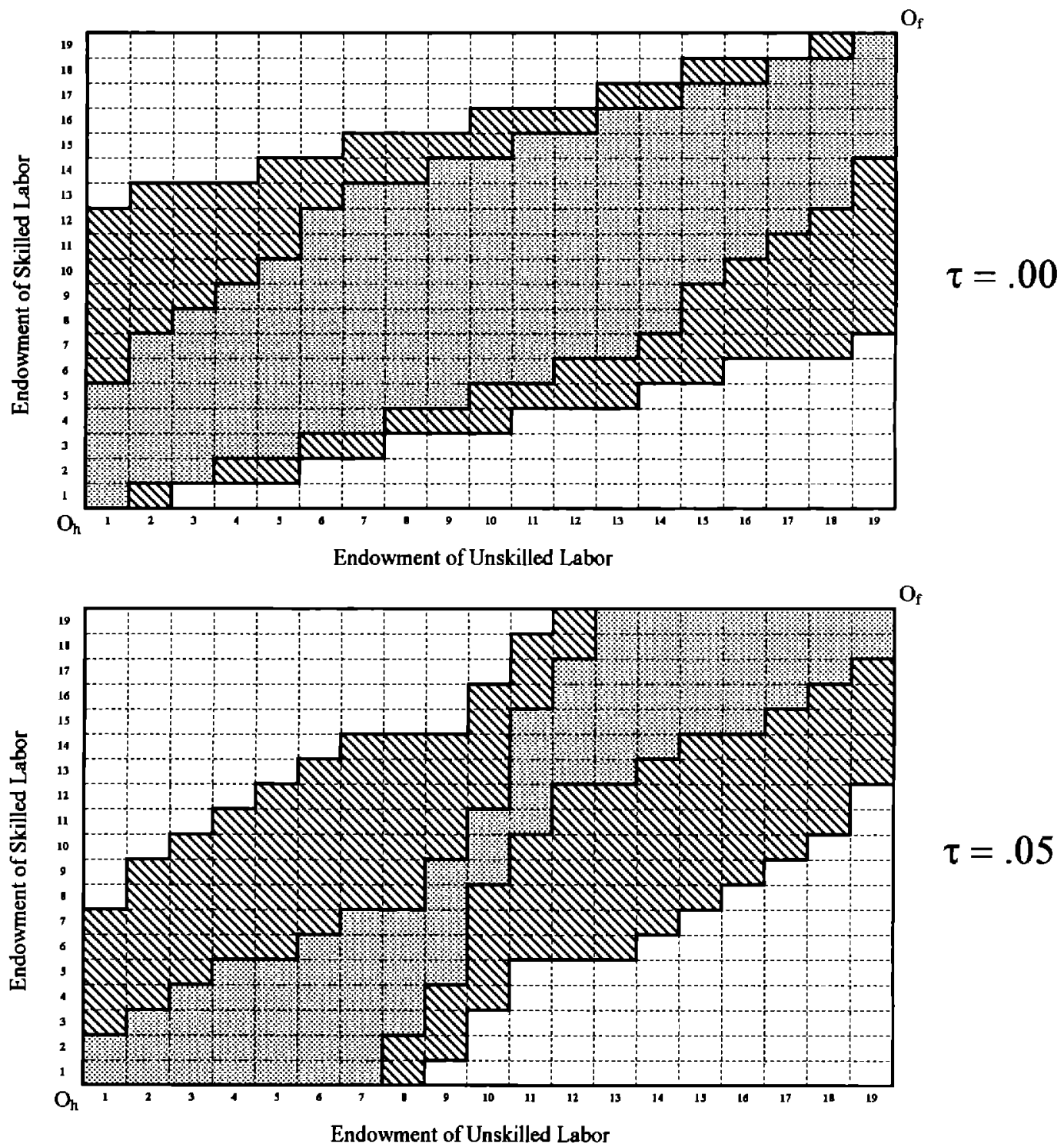

$\tau=.05$

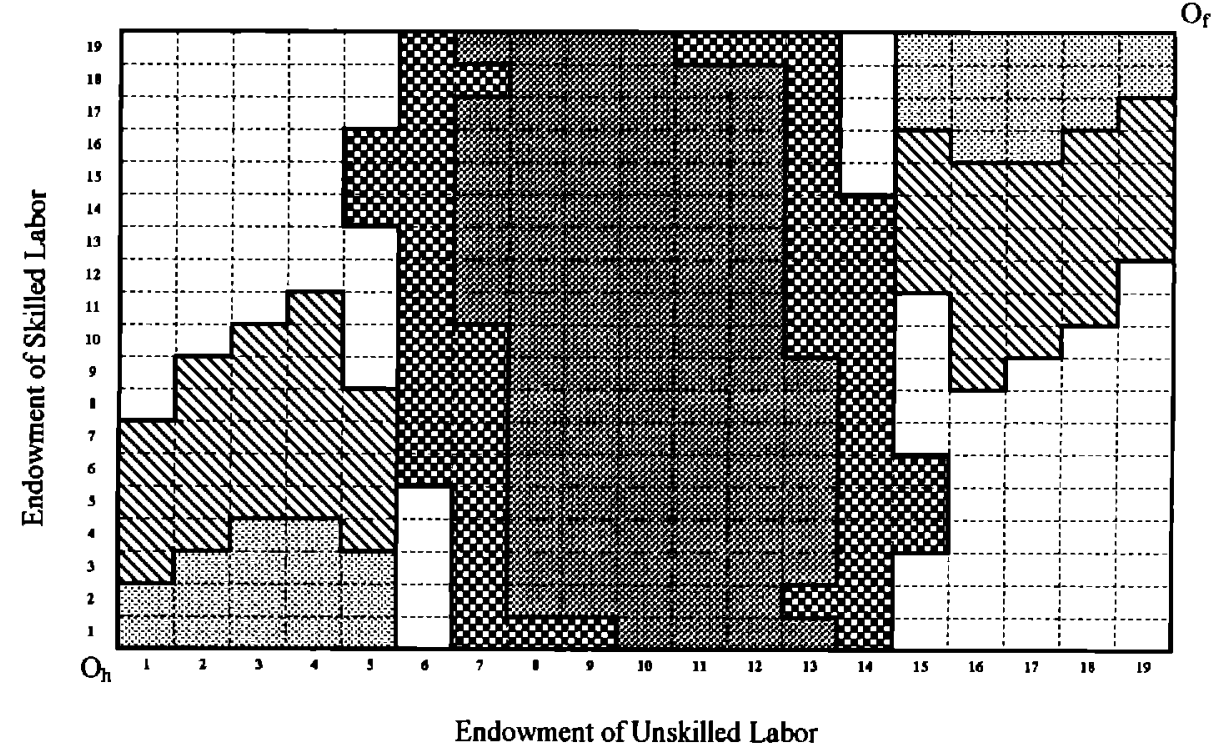

$\tau=.10$

Ratio of Affiliate Sales to Trade Volume plus Affliliate Sales

Less than .10

.10 to .29

.30 to .49 


\section{Assessing the Effects of Multinationals by Counterfactual: Multinationals Suppressed}

While much has been written on the "effects on multinationals", often it is not clear to what multinationals are being compared. What is the counterfactual against which to judge these effects? In our case, the most obvious alternative is to simply compute equilibria in which multinationals are banned by assumption, thus suppressing type-v and type-m firms. Only types $n_{h}$ and $n_{f}$ can exist in equilibria, converting the model into a standard example of the "new trade theory".

Figure 4 illustrates the trade regime for the three values of trade costs used in the preceding figures, $\tau=.00, .05$, and .10 . The striking feature of all three diagrams is the tension of relative endowments versus country size in determining the direction of trade in $\mathrm{X}$. Since $\mathrm{X}$ cannot be fragmented, it is skilled-labor-intensive overall relative to $\mathrm{Y}$, and so the skilled-labor-abundant country tends to export $\mathrm{X}$. But the $\mathrm{X}$ sector has increasing returns to scale and hence has this home-market effect mentioned several times earlier. This gives the larger of two countries a "comparative advantage" in $\mathrm{X}$ production and exports. ${ }^{10}$

These effects come across quite clearly in all three panels of Figure 4 . If country $h$ is relatively skilled-labor-abundant (points above the SW-NE diagonal), it exports $\mathrm{X}$ unless it is "significantly" smaller, where the critical value of size decreases with the difference in relative endowments. Converse comments apply to country f. Some non-monotonicity occurs in the top panel (free trade) such as row 10. Moving from left to right, country $\mathrm{h}$ first imports $\mathrm{X}$ as the countrysize effect dominates, and then exports $\mathrm{X}$ as the relative-endowment effect dominates. Crossing the diagonal the direction of trade reverses again (but this is the relative-endowment effect continuing

\footnotetext{
${ }^{10} \mathrm{Recall}$ that the factor-price ratio through the center point is very steep, so effectively country $h$ is larger in income at all points to the right of column 10 . If only country size mattered, the hatched area of country $h$ exporting $X$ in Figure 4 would be all points in the right-hand half of the diagram. If only relative endowments mattered, the hatched area would be all point above the SW-NE diagonal as in the Heckscher-Ohlin model. The Helpman-Krugman (1985) reproduces the usual Heckscher-Ohlin result because, with fixed markup rules, there are no country size effects.
} 
to dominate) and eventually trade reverse a final time as the country-size effect once again dominates.

Figure 5 puts the information of Figures 2 and 4 together to produce maps of regions where the direction of trade is reversed with the removal of the investment ban. In all three panels, trade in $\mathrm{X}$ reverses direction in the northwest and southeast regions. Basically, this is intuitive in terms of previous results. With multinationals banned, $\mathrm{X}$ sector production integrated in one location is skilled-labor-intensive relative to $\mathrm{Y}$ production. Thus the skilled-labor abundant country exports $\mathrm{X}$ as just noted. But factor-prices are unequal in these regions, with skilled labor being cheaper in the skilled-labor-abundant country. Thus if multinationals can enter, type- $\mathrm{v}_{h}$ firms will enter in the northwest corner, fragment production, concentrating headquarters activities at home and locating more unskilled-labor-intensive final production in country $f$.

The shaded regions of trade reversal in the top panel of Figure 5 are considerably harder to understand, in part because our intuitive stories tend to follow partial-equilibrium reasoning. Consider the shaded region in the southwest area of the top panel. Without multinationals, country h imports X since the country-size effect dominates the relative-endowment effect as we noted earlier. But country h also has a relatively low price for skilled labor in this region. Thus if multinationals are permitted, type- $\mathrm{v}_{\mathrm{h}}$ firms will enter, relocating headquarters activities toward country h. But this drives up the price of skilled labor in country h. In general-equilibrium, the solution is to reallocate resources in country $\mathrm{h}$, from the $\mathrm{Y}$ sector to final $\mathrm{X}$ production, the latter being less skilled-labor intensive than $\mathrm{Y}$. So investment liberalization leads to a reallocation of resources to the most skilled-labor-intensive activity (headquarters) and to the least skilled-labor-intensive activity (final production) and out of the intermediate activity Y. This reversal in the direction of trade in $\mathrm{X}$ in this SW region does not occur in the bottom two panels of Figure 5 (increased trade costs affect the direction of trade with multinationals (Figure 2), but not without (Figure 4) in this SW region).

Figure 6 plots results as to how the volume of commodity trade changes with investment 
liberalization, the hatched areas being regions of increased trade following investment liberalization. Investment and trade in goods could be termed complements in a volume sense in these regions. Roughly speaking, the results indicate that the investment liberalization increases the volume of trade when the moderately skilled-labor abundant country is also moderately smaller.

These results are not easy to interpret. In each of the panels of Figure 6, some of the hatched points of increased trade volume coincide with point of trade-direction reversal in Figure 5 while the majority do not. What is true is that all of the hatched points in all panels of Figure 6 involve mixed regimes type-n and type-v firms when multinationals are permitted. No points involve type-v firms only (and obviously not type-n firms only).

The second interesting feature of these hatched point of increased trade volume is that almost all of them involve essentially no change in the gross volume of $\mathrm{X}$ sector trade, indeed many involve a small fall in this volume. What accounts for the increased trade volume is an increase in the net volume of $\mathrm{X}$ sector trade and a rise in the volume of $\mathrm{Y}$ trade (note that net trade in $\mathrm{X}$ and trade in $\mathrm{Y}$ need not be the same because of trade in services). Thus, while the gross volume of trade in $\mathrm{X}$ is not increasing, there is a fall in intra-industry (cross-hauling) trade in $\mathrm{X}$ as countries become more specialized. The country with the lower price for skilled labor in the absence of multinationals becomes more specialized in headquarters' services and less specialized in final production when investment is liberalized. In the left-hand "blob" of hatched points in the middle panel of Figure 6 for example, country $\mathrm{h}$ becomes more specialized in $\mathrm{Y}$ and $\mathrm{S}$ and less specialized in $\mathrm{X}$ production when investment is liberalized. At some of the upper points in this blob the direction of trade in $\mathrm{X}$ is reversed, from exporting to importing $\mathrm{X}$ while in the lower point imports of $\mathrm{Y}$ are reinforced by investment liberalization.

The only exception to this result is some points at the extreme right and left-hand edges of the upper panel of Figure 6, where investment liberalization does lead to increased intra-industry 
trade in $\mathrm{X}$, and to very little change in the net volume of trade in $\mathrm{X}$. At the left-hand edge for example, investment liberalization leads to a switch in the direction of trade in $\mathrm{X}$ as we noted above, with country $\mathrm{h}$ exporting $\mathrm{X}$ after liberalization (country $\mathrm{h}$ switches from being relatively specialized in $\mathrm{Y}$ to being relatively specialized in headquarters services and final $\mathrm{X}$ production). This generates more cross hauling of $\mathrm{X}$ with little increase in the net trade in $\mathrm{X}$ (just a reversal in direction). 
Figure 4: Trade Regime Diagrams, Multinationals Suppressed
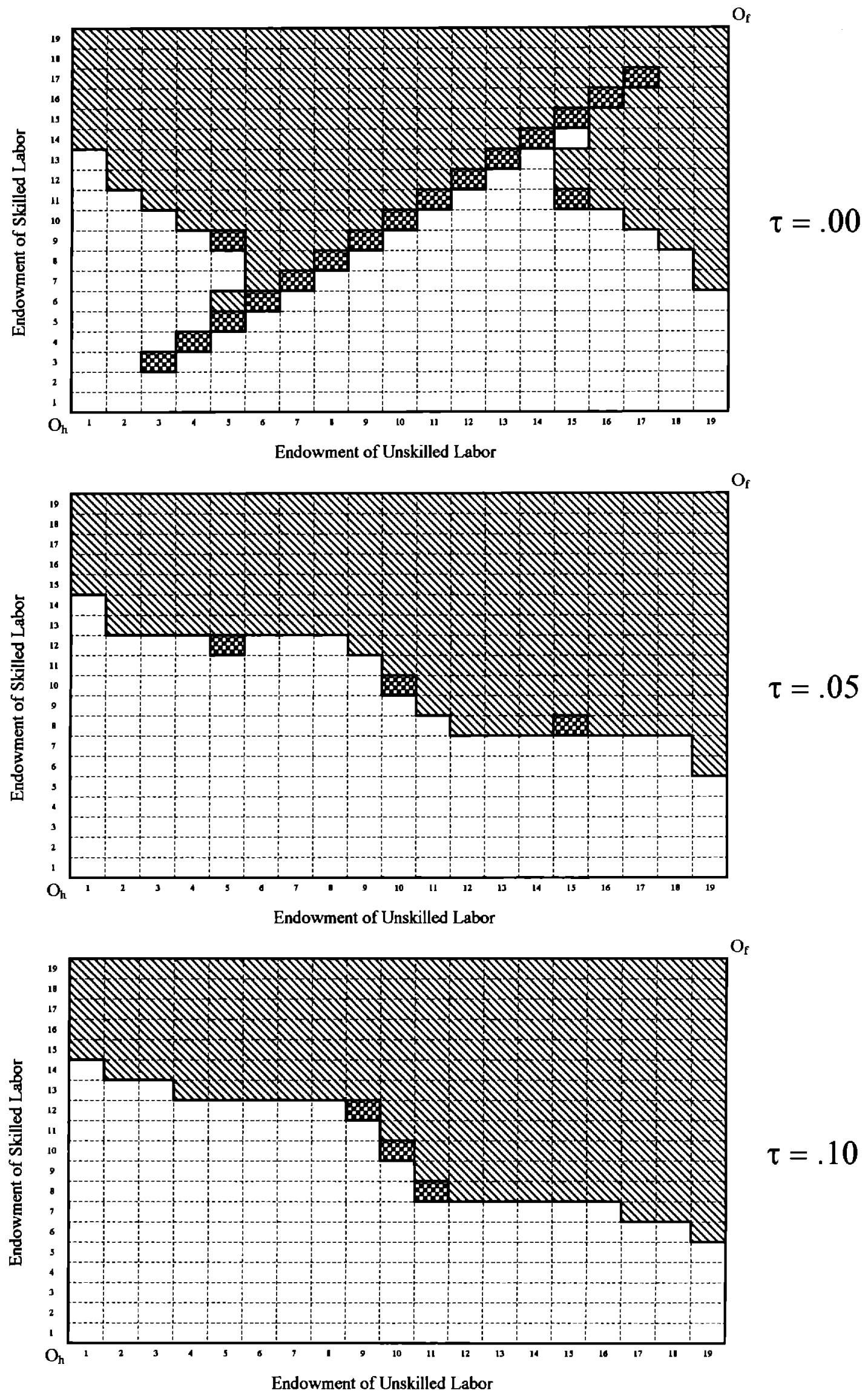

Country h Exports X Country h Imports X No Trade 
Figure 5: Reversals in the Direction of Trade with and without Multinationals
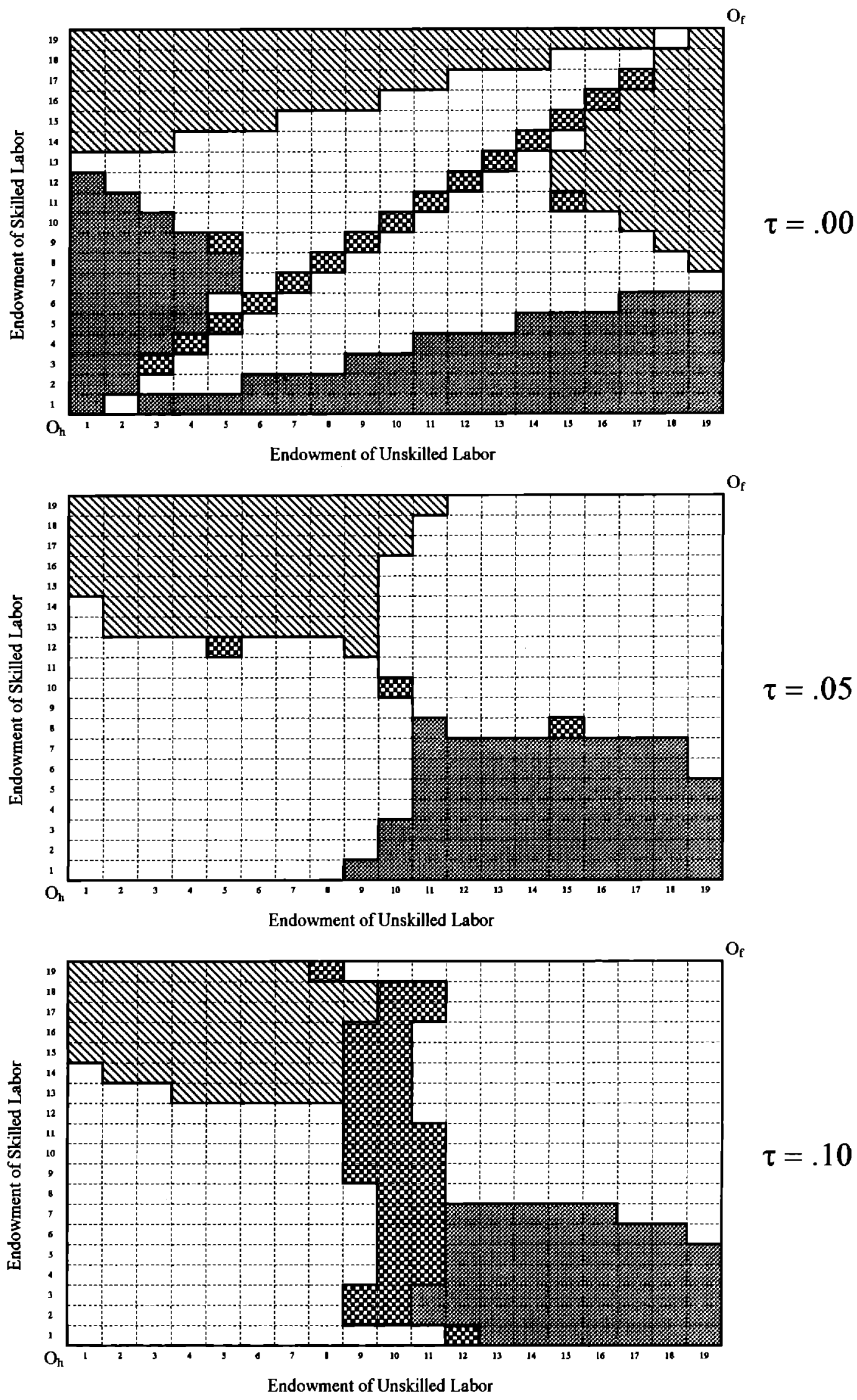

Country h Imports X with MNEs, Exports X with MNEs Suppressed Country h Exports $X$ with MNEs, Imports X with MNEs Suppressed Directtion of Trade in $\mathrm{X}$ the Same with and without MNEs

No Trade in $\mathrm{X}$ in one or both Cases 
Figure 6: Changes in the Volume of Trade with and without Multinationals
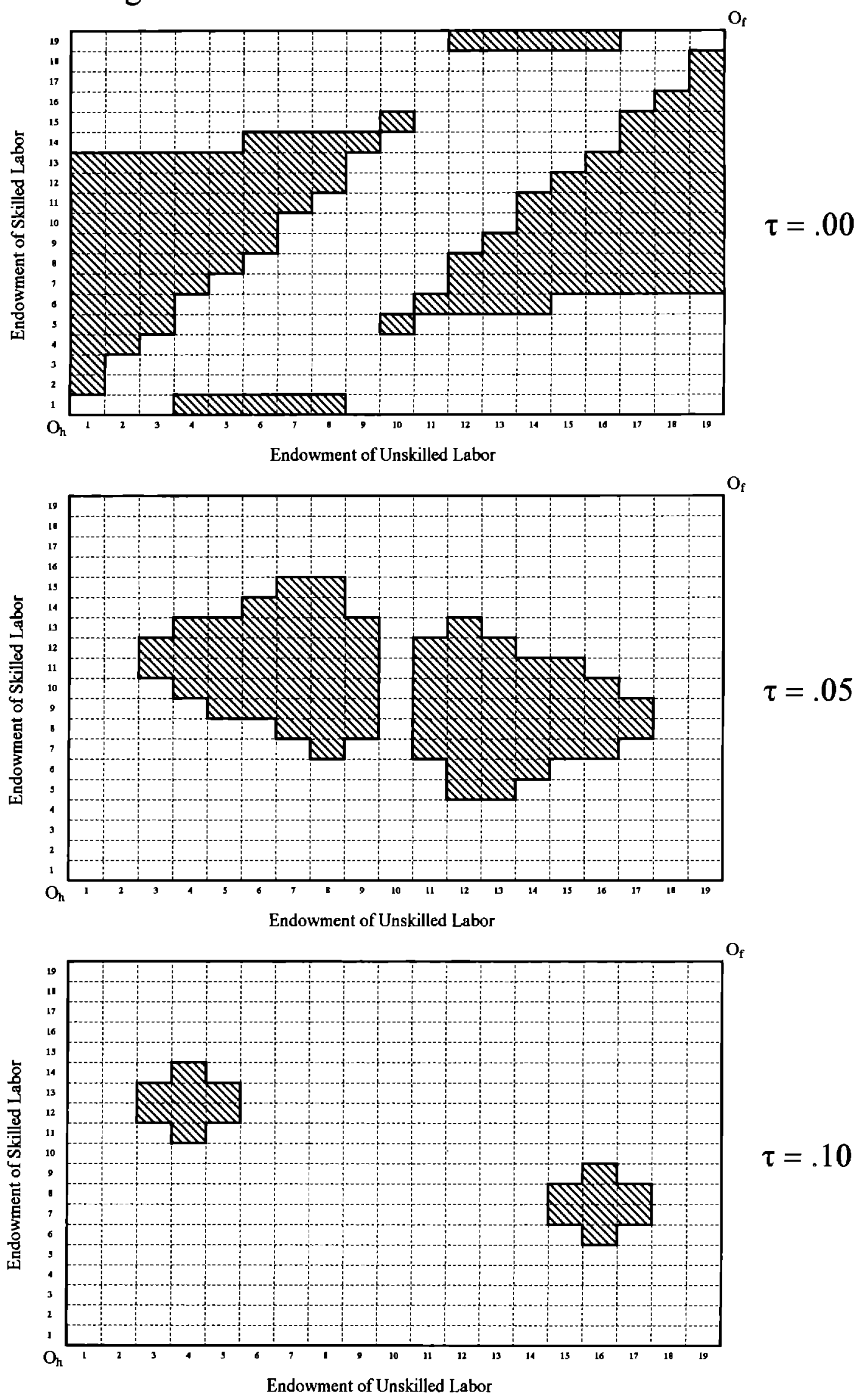

Trade Volume falls or is constant when Multinationals are Permitted

Trade Volume increases when Multinationals are Permitted to Enter 


\section{Factor Prices and Welfare}

Our final set of results have to do with the effects of multinationals on factor prices and welfare. Again, we will use the counterfactual of no multinationals permitted as a counterfactual against which to compare the effects of direct investment.

Figures 7 through 9 present results on the ratio of the skilled to unskilled wage rate in country $\mathrm{h}$. The panels correspond to the trade costs $\tau=.00, .05$, and .10 , and in each diagram the top panel is for multinationals permitted and the bottom panel for multinationals banned. It is immediately obvious that multinationals constitute an important force toward factor-price equalization. In each diagram, most of the area in the top panel has a value of $\mathrm{z}_{\mathrm{h}} / \mathrm{w}_{\mathrm{h}}$ of between $98 \%$ and $102.04 \%$ (inverse of $98 \%$ ) of its value at the center point of the factor box. It is interesting to note that the size of this region is not very sensitive to the level of trade costs.

The bottom panels in Figures 7-9 tell a rather different story. Factor prices diverge rather sharply from the center point as countries become different in relative endowments. The degree of divergence again is not very sensitive to trade costs, except that the size of the $98 \%-102 \%$ region becomes very small with non-zero trade costs.

The diagrams suggest that investment liberalization generates a strong tendency toward factorprice equalization regardless of whether the entering firms are type-v firms or type-m firms (central region of Figure 9). We have already commented on the role of factor-price differences in inducing entry of type-v firms. Briefly, unequal factor prices induce the entry of type-v firms, which fragment the $\mathrm{X}$ sector, locating skilled-labor-intensive headquarters activities in the country where $\mathrm{S}$ is cheap (generally the skilled-labor-abundant country) and final production where $\mathrm{L}$ is cheap. This then creates a pressure toward factor-price equalization. In the case of type-m firms, they do something similar. Since there is only one headquarters, the potential type-m firm chooses the country in which skilled labor is cheaper. In general equilibrium, this creates a similar pressure toward factor-price 
equalization.

Our final results in Figure 10 plot areas in which the removal of a prohibitive investment ban might lead to a fall in welfare (hatched areas). ${ }^{11}$ Using good $\mathrm{Y}$ as numeraire and setting expenditure shares equal to $1 / 2$ as in our simulations, the indirect utility function for country $h$ is

$$
U_{h}=\left(w_{h} \bar{L}_{h}+z_{h} \bar{S}_{h}\right) p_{x}^{-1 / 2} / 2
$$

Thus changes in welfare can arise either from factor-price changes or a change in the price of $\mathrm{X}$. Although the general-equilibrium effects do not permit a very simple answer, most of the hatched points in Figure 10 are associated with a rise in $\mathrm{p}_{\mathrm{x}}$ for country $\mathrm{h}$ following the removal of an investment ban. In the hatched areas in the upper left-hand corners, recall that the direction of trade actually reverses following investment liberalization, with country $\mathrm{h}$ having to import $\mathrm{X}$ from country f. In the hatched regions on the far right, the removal of the investment ban is associated with a transfer of production of $X$ from country $h$ to country $f$ in most but not all of the hatched cells. We think that this is interpreted as a loss of home-market advantage for country $h$, with an associated loss of $\mathrm{X}$ production and rise in price. In any case, it is possible for investment liberalization to leave a country worse off if it is (a) small but very well endowed with skilled labor, or (b) large and somewhat abundant in unskilled labor.

\footnotetext{
${ }^{11}$ We have tried to avoid putting any emphasis on quantitative results in this paper. Since this is a pure simulation model, numerical values seem to have no particular interpretation. We break the silence here and note that in almost all of the hatched points of Figure 10, the welfare loss following trade liberalization is less than $1 \%$.
} 


\section{Figure 7: Ratio of Skilled to Unskilled Wage, Transport Costs $\tau=.00$}

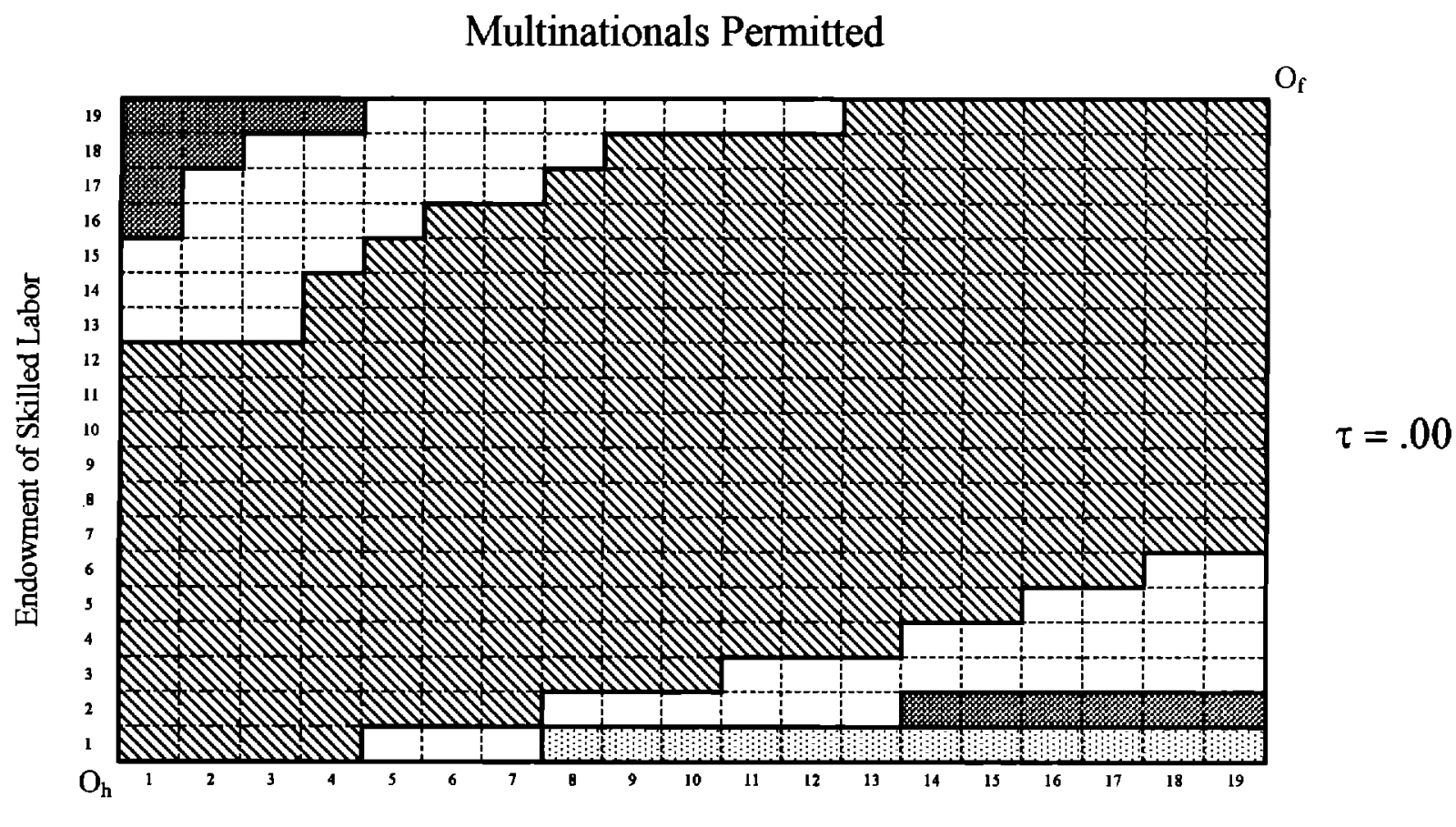

Endowment of Unskilled Labor

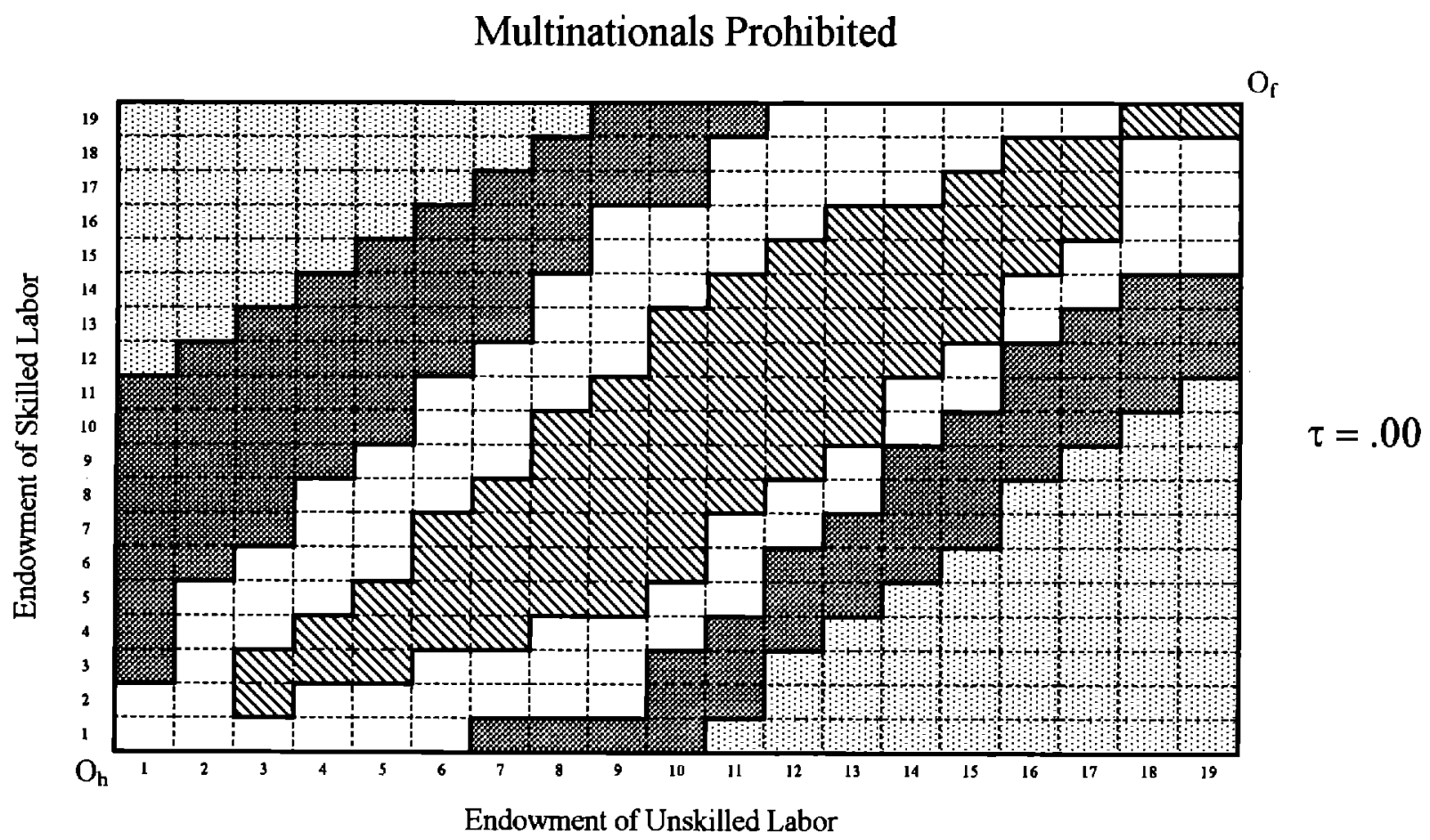

zh/wh within $98 \%$ (or reciprocal) of center point zh/wh between $98 \%$ and $75 \%$ (or reciprocals) of center point zh/wh between $75 \%$ and $50 \%$ (or reciprocals) of center point $\mathrm{zh} / \mathrm{wh}$ less than $50 \%$ (or greater thanreciprocal) of center point 


\section{Figure 8: Ratio of Skilled to Unskilled Wage, Transport Costs $\tau=.05$}

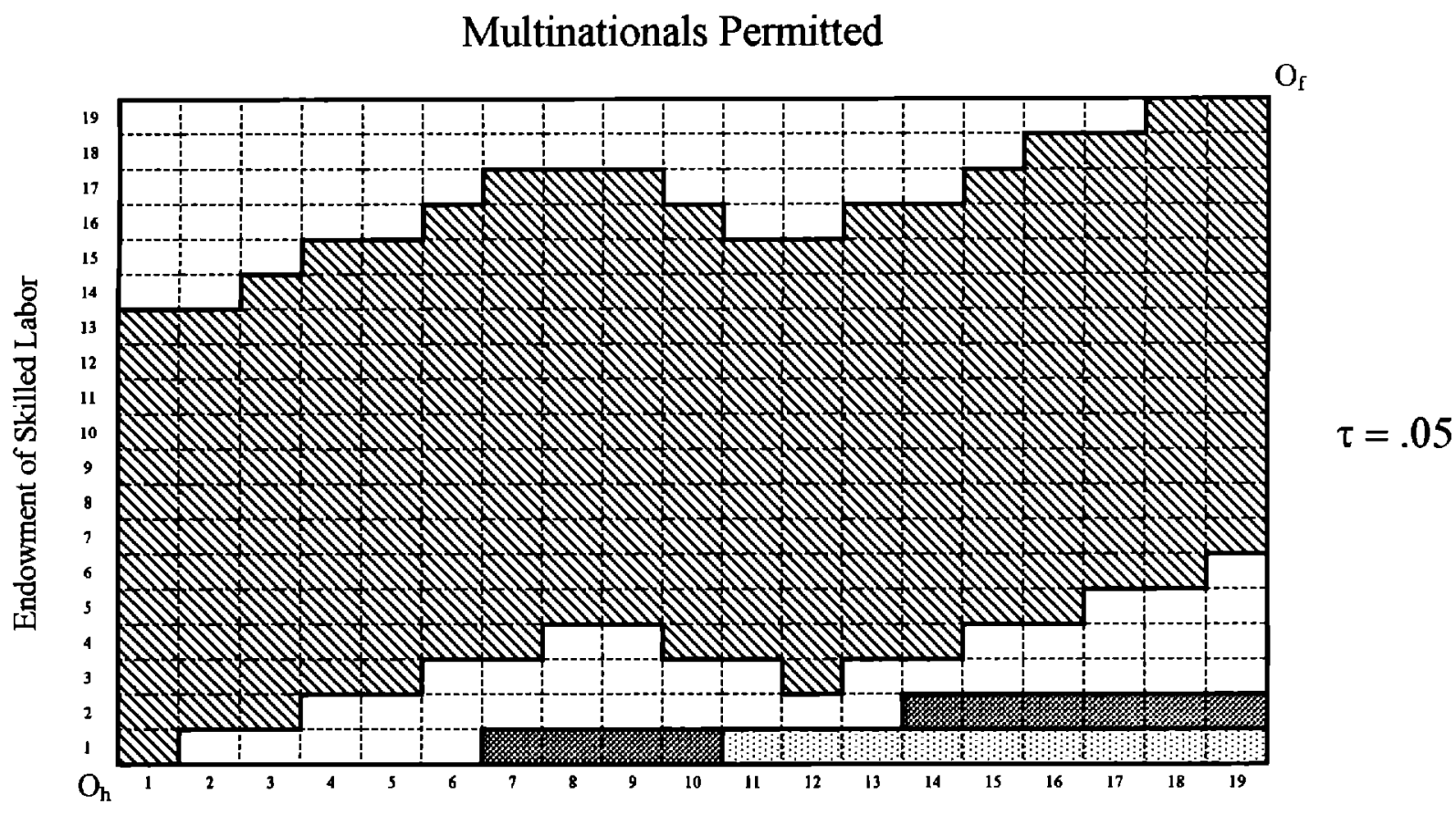

Endowment of Unskilled Labor
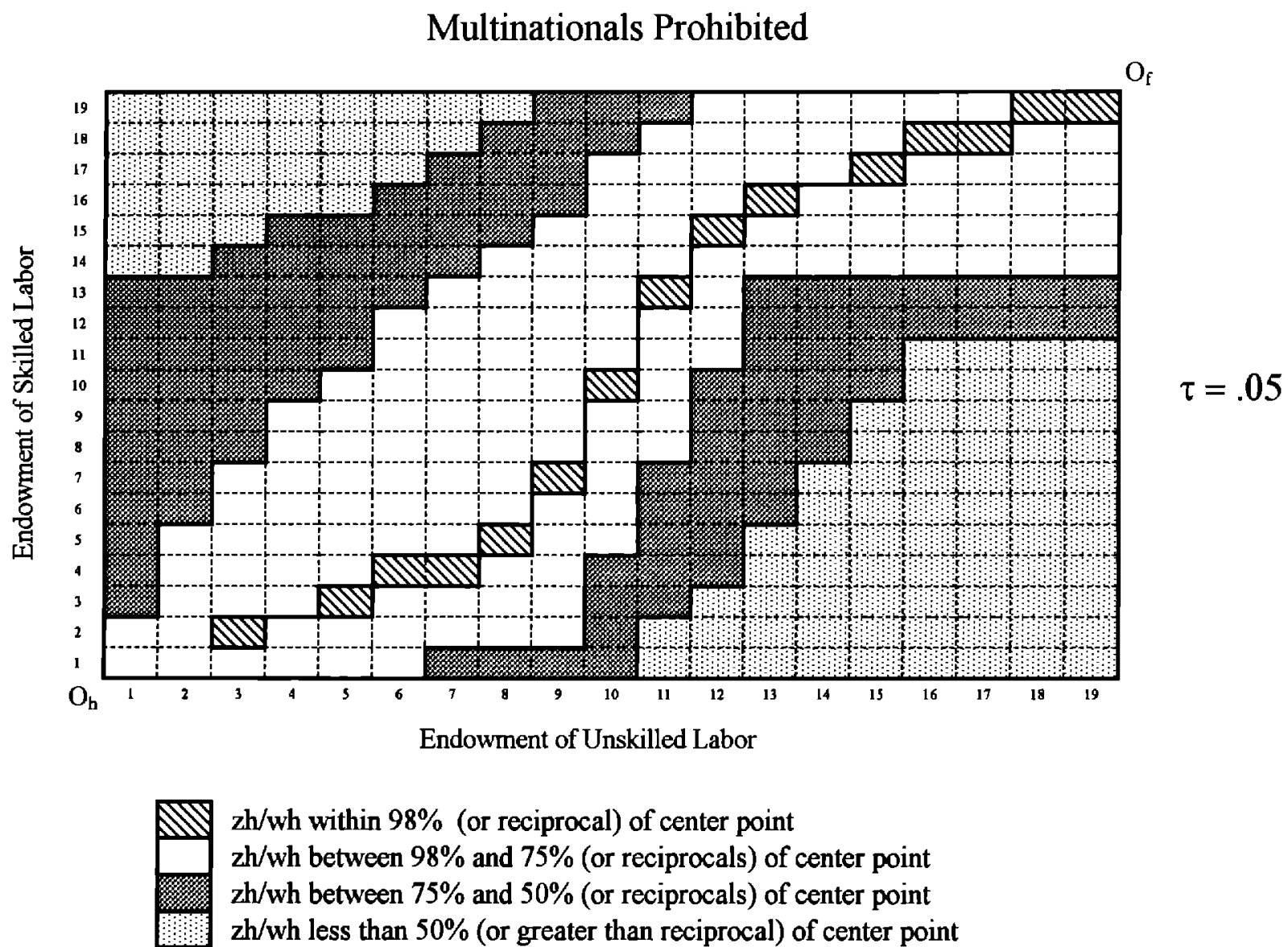

$\mathrm{zh} /$ wh within $98 \%$ (or reciprocal) of center point zh/wh between $98 \%$ and $75 \%$ (or reciprocals) of center point $\mathrm{zh} / \mathrm{wh}$ between $75 \%$ and $50 \%$ (or reciprocals) of center point $\mathrm{zh} / \mathrm{wh}$ less than $50 \%$ (or greater than reciprocal) of center point

(Center point continues to refer to the center point of the chart with $t=.00$ ) 


\section{Figure 9: Ratio of Skilled to Unskilled Wage, Transport Costs $\tau=.10$}

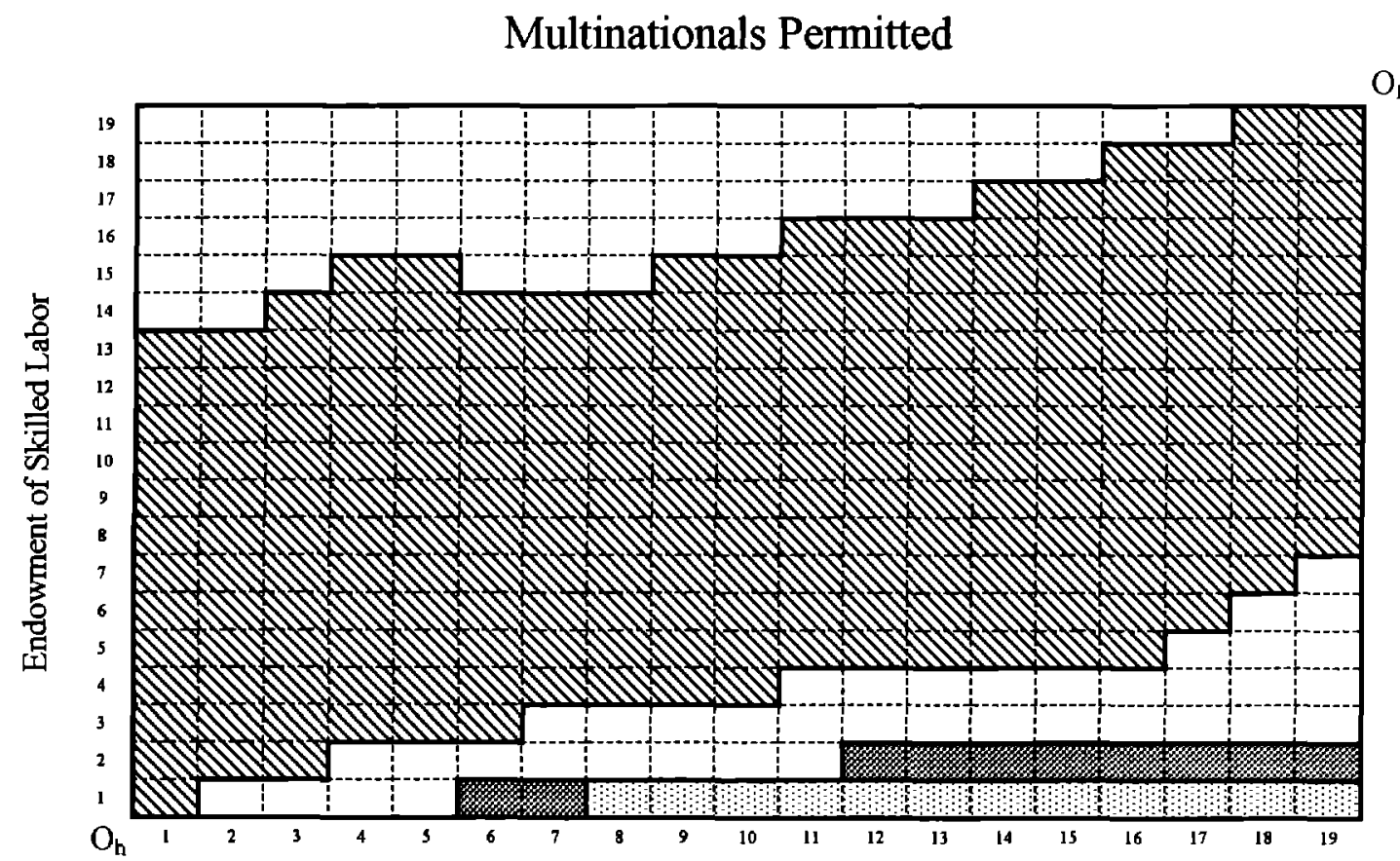

$\tau=.10$

Endowment of Unskilled Labor

\section{Multinationals Prohibited}

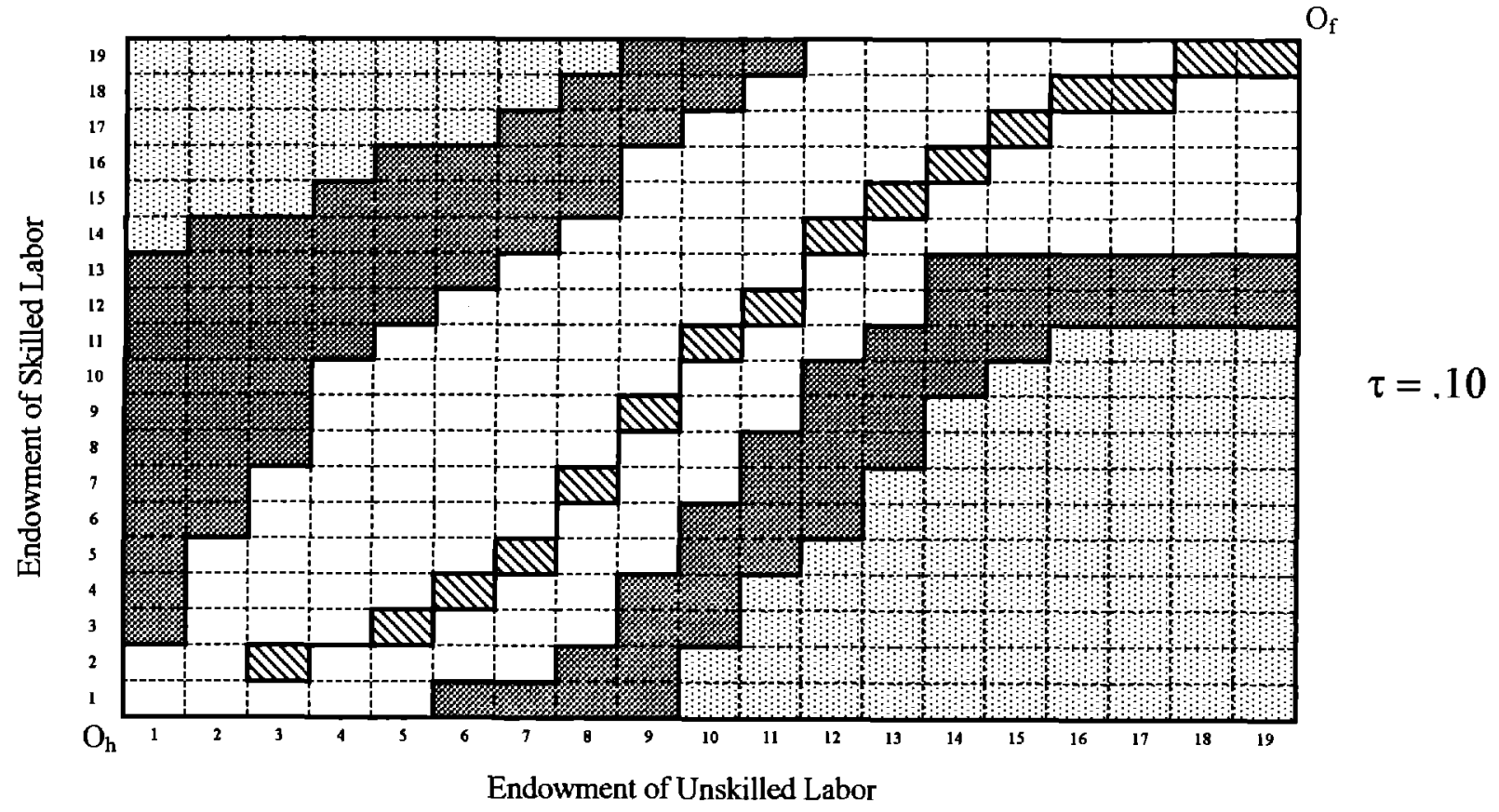

$\mathrm{zh} /$ wh within $98 \%$ (or reciprocal) of center point zh/wh between $98 \%$ and $75 \%$ (or reciprocals) of center point zh/wh between $75 \%$ and $50 \%$ (or reciprocals) of center point zh/wh less than $50 \%$ (or greater than reciprocal) of center point

(Center point continues to refer to the center point of the chart with $t=.00$ ) 
Figure 10: Changes in Country h's Welfare Following Investment Liberalization
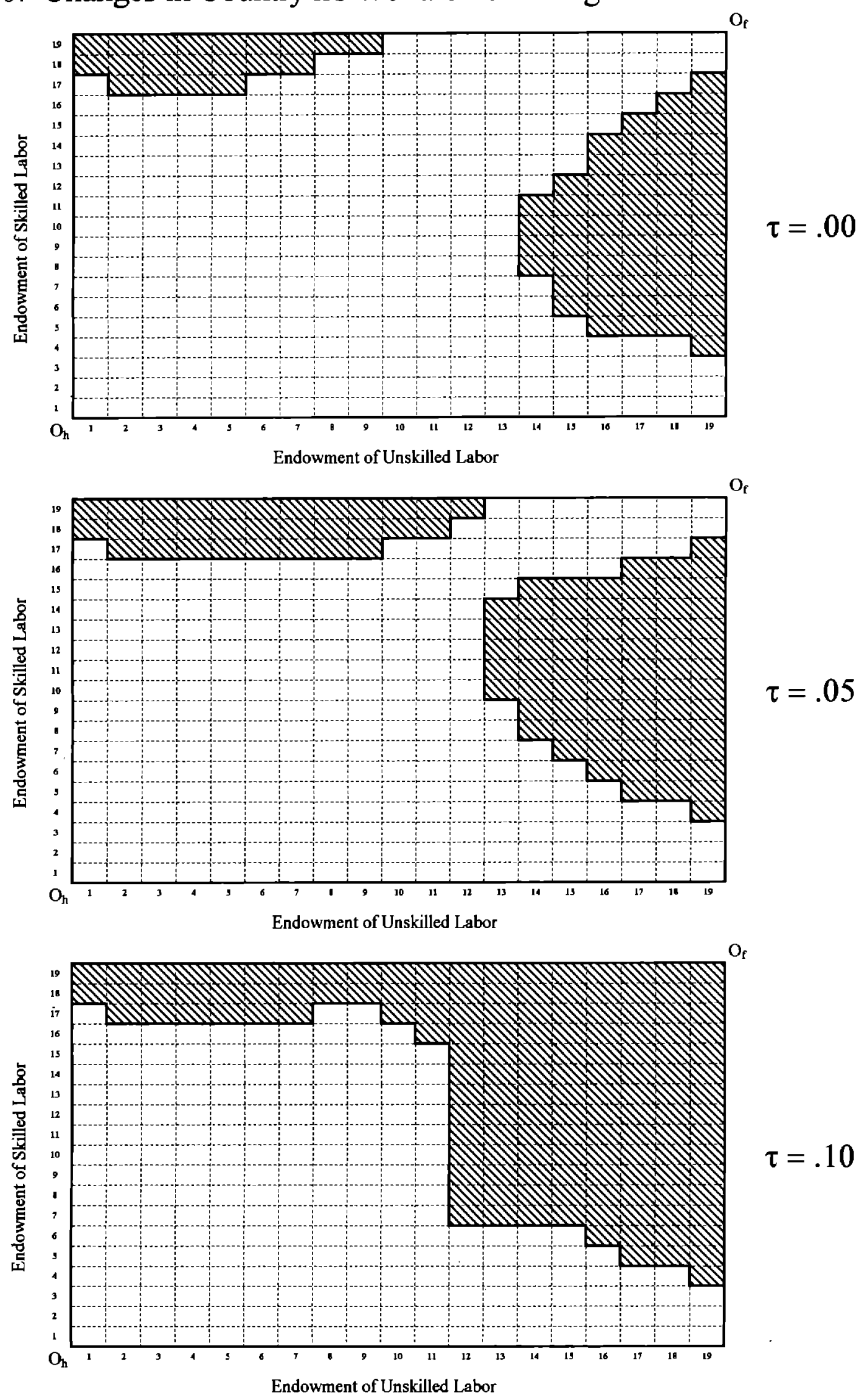

Country h's welfare increases or is constant when Multinationals are Permitted

Country h's welfare falls when Multinationals are Permitted to Enter 


\section{Summary and Conclusions}

The purpose of this paper is to provide an integrated treatment of a number of strand of literature in which one sector of the economy produces with increases returns to scale and imperfect competition. One branch is often referred to as the "new trade theory" in which single-plant national firms compete with national firms of another country in the international market place. A second branch involves endogenous "horizontal" multinational firms which choose between serving a foreign market by exports and serving it by building a branch plant. A third branch involves "vertical" multinationals which maintain single plants, but which geographically separate headquarters activity from production. In the present paper, all of these models arise as special cases for some set of parameter values.

(1) Our first task was to characterize the production regime: the types of firms active in equilibrium. Broadly speaking, single-plant national firms (with headquarters and the plant in the same location) dominate in equilibrium when the countries are similar in relative endowments and dissimilar in size. They can also arise when sizes are similar provided trade costs are low. Vertical multinationals (one plant with headquarters and plant in different countries) dominate when the countries are sufficiently dissimilar in relative endowments but somewhat similar in size. Two-plant horizontal multinationals dominate when the countries are similar in size and in relative endowments, and trade costs are moderate to high.

(2) We then examined the trade regime: which countries export X, Y, and services. Here the assumptions on factor intensities are crucial. Integrated production of $\mathrm{X}$ is more skilled-laborintensive than $\mathrm{Y}$ but decomposing $\mathrm{X}$, headquarters activities use only skilled labor and final $\mathrm{X}$ production is less skilled-labor-intensive than Y. Results indicate that the skilled-labor-abundant country is like to import $\mathrm{X}$ (vertical multinationals headquartered in that country dominate) when the countries are different in relative endowments but not extremely different in size. 
(3) An interesting statistic which is often cited empirically (although measured in a variety of ways) is the ratio of sales by affiliate of multinationals to that amount plus the volume of commodity trade. Our results indicate that this ratio is moderately high when the countries differ significantly in relative endowments (vertical multinationals dominate). It is very high if trade costs are moderate to high and the countries are similar in both relative endowments and size (but zero under the latter circumstance if trade costs are zero).

(4) We introduced an explicit counter-factual against which to judge the effects of multinationals by running the model with multinationals suppressed (e.g., a prohibitive investment ban). Several interesting results follow. First, over a considerable subset of the parameter space examined, the removal on an investment ban reverses the direction of trade in X. The multinational's ability to fragment production into skilled-labor-intensive and unskilled-labor-intensive activities often means, for example, that the skilled-labor-abundant country switches from exporting to importing X (but exporting headquarters services) following the removal of a ban.

Investment liberalization can also lead to an increase in the volume of trade. In most instances when this happens, it appears to be driven by increased specialization within the $\mathrm{X}$ sector and a fall in intra-industry trade in X. So, for example, the skilled-labor-abundant country may concentrate on headquarters activities following investment liberalization and the other country concentrate more on final production. While the total trade in $\mathrm{X}$ may not change at all, net trade increases and so the balancing volume of trade in $\mathrm{Y}$ increases.

(5) A final section of the paper considered factor prices and welfare, again using the counterfactual of an investment ban as a standard for comparison. We showed that investment liberalization created a strong tendency toward factor-price equalization at all levels of trade costs. The overall welfare effects of investment liberalization for a country are more complex and puzzling. Cases where a country loses from liberalization are generally associated with the country having high levels 
of $\mathrm{X}$ production and exports without multinationals, but having that advantage eroded following investment liberalization. This is consistent with established understanding about "home market advantages" in scale-intensive industries.

(6) As a final comment, we might point out how fragile the "strategic-trade-policy" literature looks in light of our results. That literature focusses on cases of single-plant, domestically-owned firms competing against like firms from the other country. This type of situation does exist in our model, but over a very small part of parameter space (whatever that might measure). And of course, it is clear that small changes in trade costs or other policy parameters might induce a regime shift, so that the policy prescription based on an exogenous regime may be completely inappropriate. 


\section{REFERENCES}

Brainard, S. Lael, "A Simple Theory of Multinational Corporations and Trade with a Trade-off between Proximity and Concentration", NBER Working Paper No. 4269, February 1993 a.

Brainard, S. Lael, "An Empirical Assessment of the Factor Proportions Explanation of Multinationals Sales", NBER Working Paper No. 4580, December 1993b.

Brainard, S. Lael, "An Empirical Assessment of the Proximity-Concentration Tradeoff between Multinational Sales and Trade", NBER Working Paper No. 4583, December 1993c.

Dixit and Norman, The Theory of International Trade, London: Cambridge University Press. 1980.

Ekholm, Karolina, Multinational Production and Trade in Technical Knowledge, Lund Economic Studies number 58, 1995.

Helpman, Elhanan, "A Simple Theory of Trade with Multinational Corporations", Journal of Political Economy, 1984, 92, 451-471.

Helpman, Elhanan, "Multinational Corporations and Trade Structure", $\underline{\text { Review of Economic Studies, }}$ $1985,52,443-458$.

Helpman, Elhanan and Paul R. Krugman, Market Structure and Foreign Trade, Cambridge: MIT Press. 1985.

Horstmann, Ignatius J. and James R. Markusen, "Endogenous Market Structures in International Trade," Journal of International Economics, 1992, 32, 109-129. Reprinted in J. Peter Neary (editor), International Library of Critical Writings in Economics: International Trade, London: Edward Elgar (1995).

Konan, Denise Eby, "The Vertical Multinationals Enterprise and International Trade", University of Hawaii Working Paper, December 1995

Markusen, James R., "Factor Movements and Commodity Trade as Complements", Journal of International Economics 13 (1983), pp. 341-356. Reprinted in J. Peter Neary (editor), International Library of Critical Writings in Economics: International Trade, London: Edward Elgar (1995).

Markusen, James R., "Multinationals, Multi-Plant Economies, and the Gains from Trade", Journal of International Economics 1984, 16, 205-226. Reprinted in Jagdish Bhagwati (ed.), International Trade: Selected Readings, second edition, MIT Press (1988).

Markusen, James R. (1995), "The Boundaries of Multinational Firms and the Theory of International Trade", Journal of Economic Perspectives 9, 169-189.

Markusen, James R. and Anthony J. Venables), "Multinational Firms and the New Trade Theory", NBER Working Paper 5036, 1995. 
Markusen, James R. and Anthony J. Venables, "Multinational Production, Skilled Labor, and Real Wages", NBER Working Paper 5483, 1996a.

Markusen, James R. and Anthony J. Venables, "The Theory of Endowment, Intra-Industry, and Multinational Trade", CEPR working paper 1341, $1996 \mathrm{~b}$.

Motta, Massimo, "Multinational Firms and the Tariff-Jumping Argument", European Economic Review, 1992 36, 1557-1571.

Rutherford, Thomas F., "Applied General-Equilibrium Modelling with MPS/GE as a GAMS subsystem", unpublished manuscript, 1994.

Rutherford, Thomas F., "Extensions of GAMS for Complementarity Problems Arising in Applied Economics", Journal of Economic Dynamics and Control, 1995.

Teece, David, The Multinational Corporation and the Resource Cost of International Technology Transfer, Cambridge: Ballinger. 1986.

Teece, David, "Technology Transfer By Multinational Firms: The Resource Cost of Transferring Technological Know-How", Economic Journal, 1977, 87, 242-61.

Zhang, Kevin, "A Model of International Trade with Vertical Multinationals", University of Colorado Working Paper, 1996. 
Appendix: Complete Regime Diagrams for Figure 1

Figure A1: Production Regime with Zero Transport Costs, $\tau=.00$

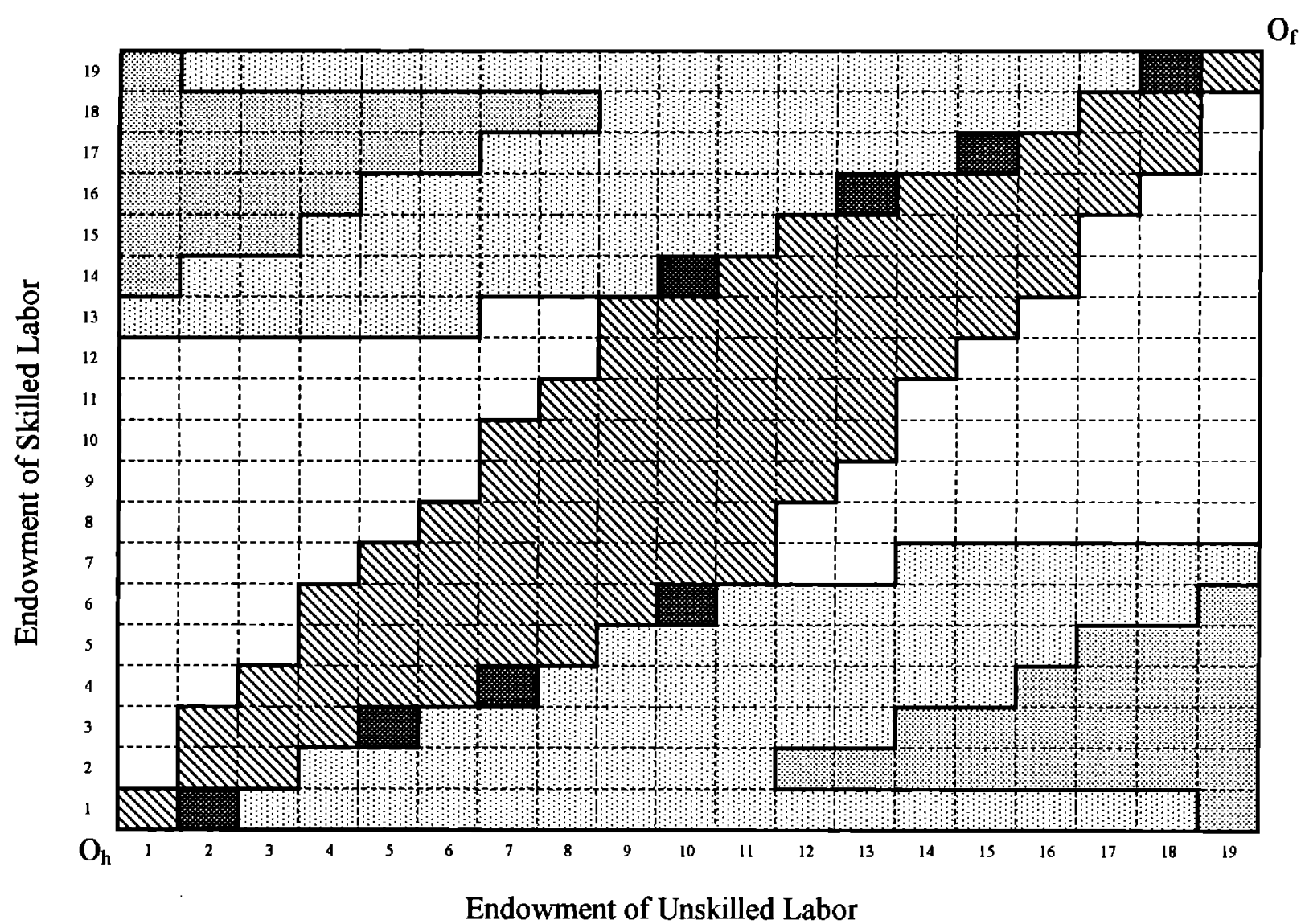

Above Diagonal

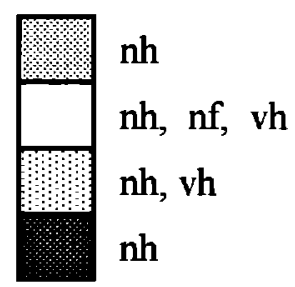

Below Diagonal

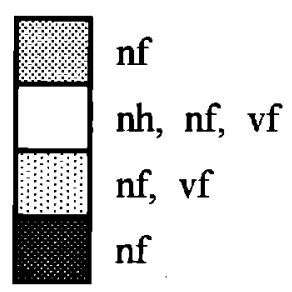

$n h, n f$ 
Figure A2: Production Regime with Low Transport Costs, $\tau=.05$

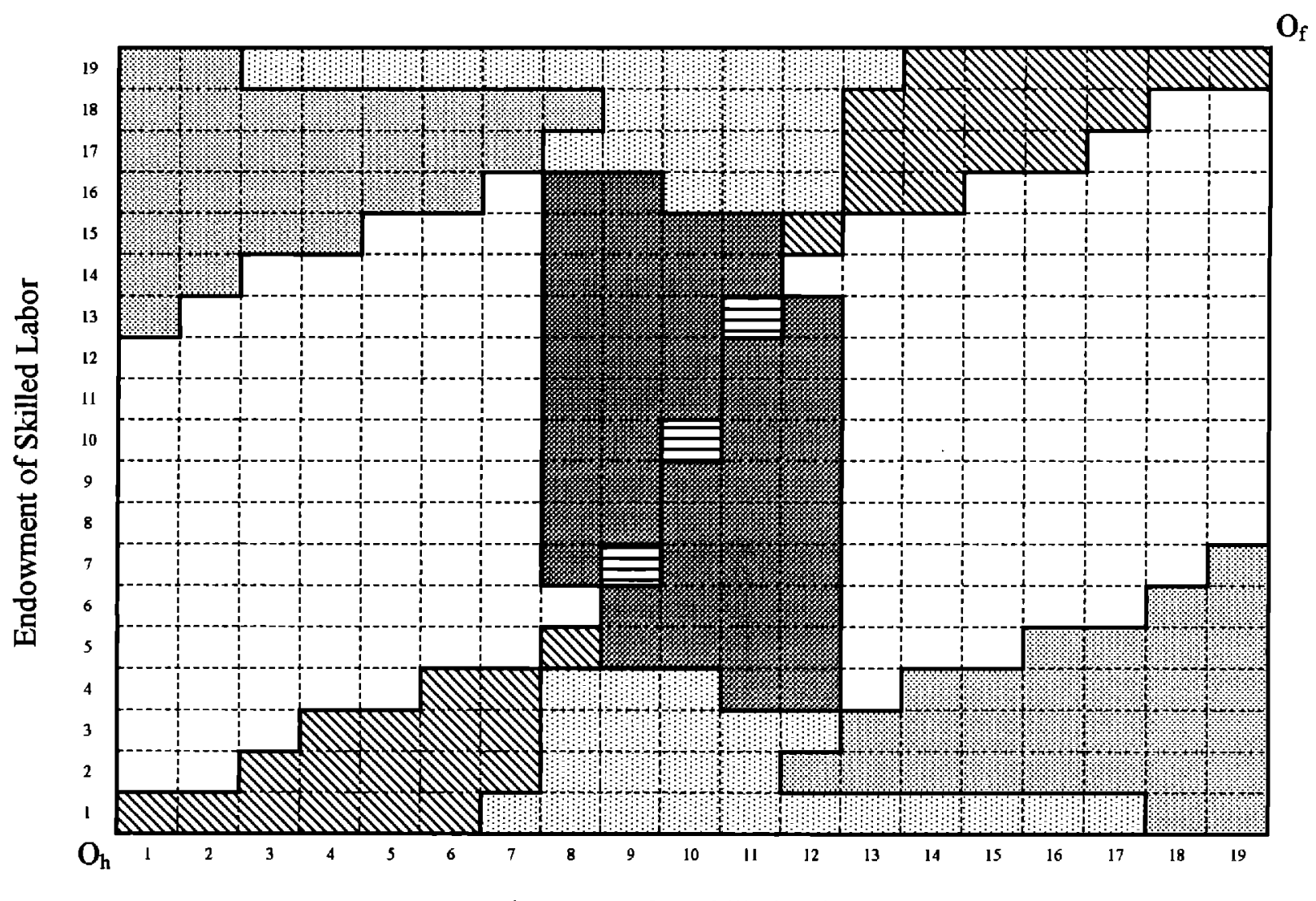

Endowment of Unskilled Labor

Above Diagonal

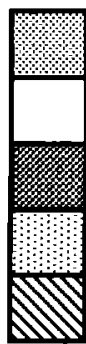

Below Diagnal

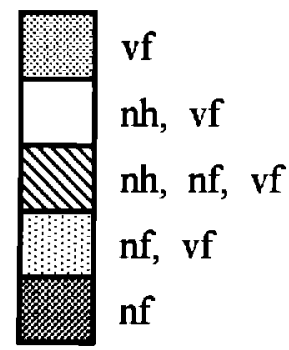

nh, nf 
Figure A3: Simplified Production Regime with Moderate Transport Costs,

$$
\tau=.10
$$

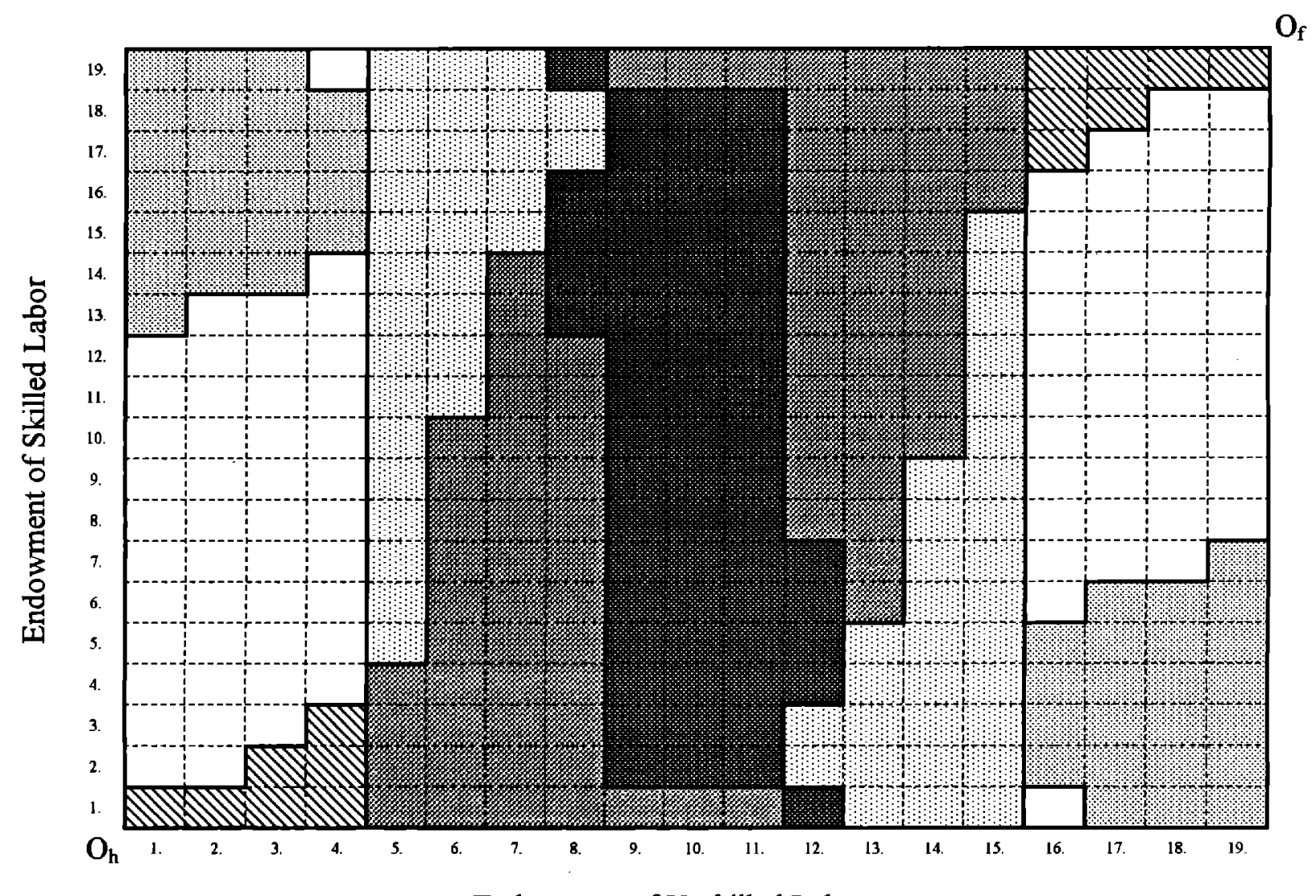

Endowment of Unskilled Labor

Type $v$ firms only

Types $n$ and $v$ firms

Type $n$ firms only

Type $m$ firms only

Types $n$ and $m$ firms

Other mixed regimes 
Figure A4: Production Regime with Moderate Transport Costs, $\tau=.10$

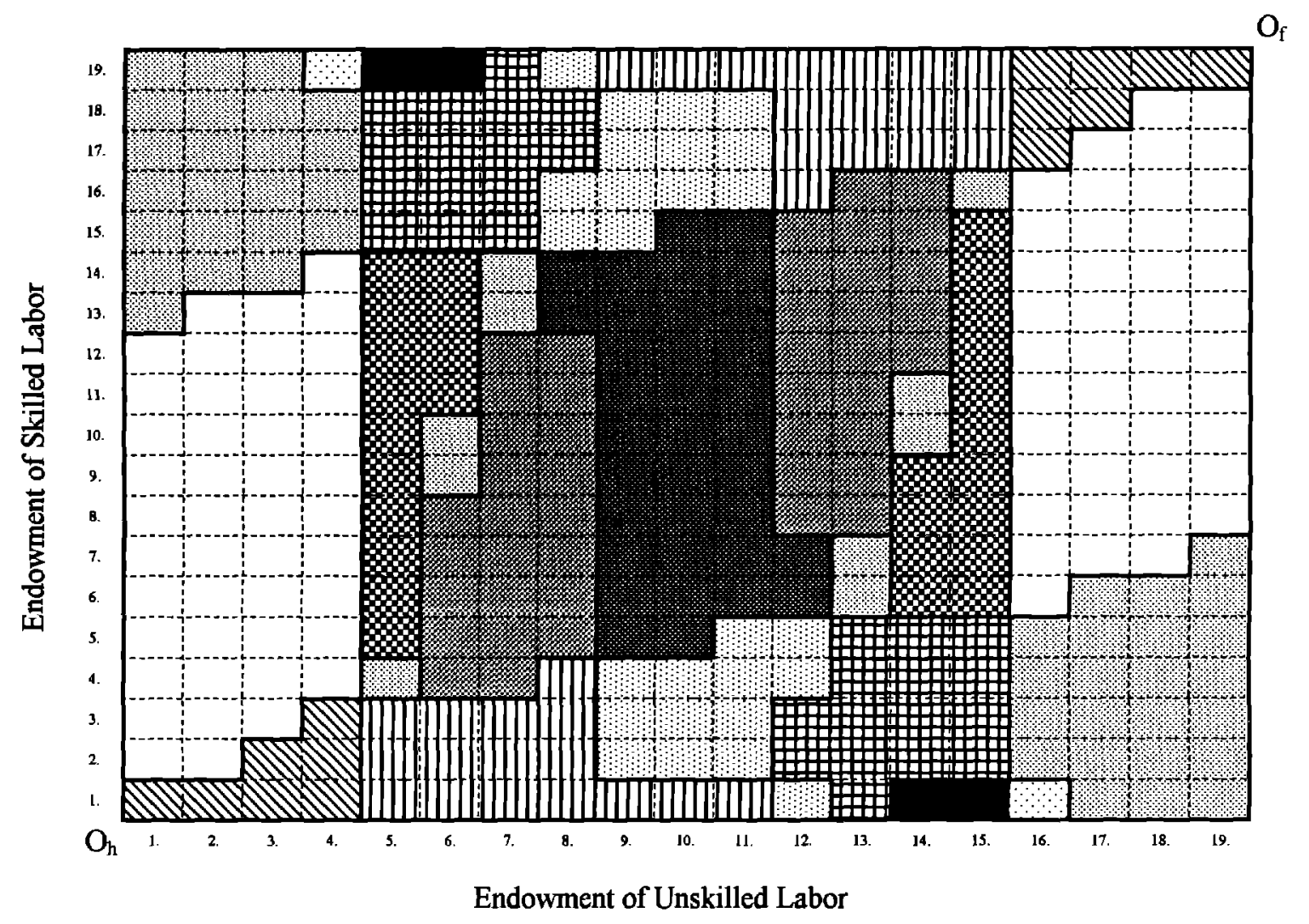

Above Diagonal

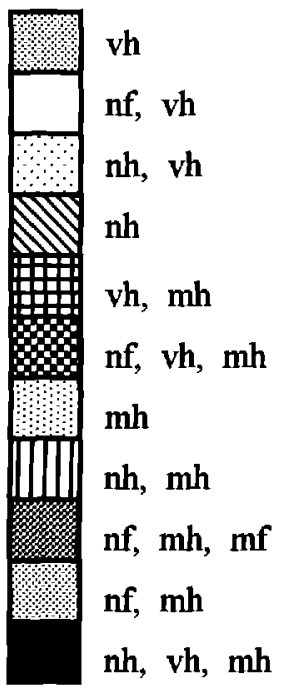

Below Diagonal

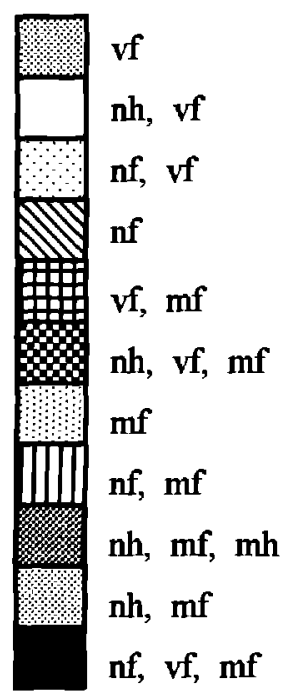

$\mathrm{mh}, \mathrm{mf}$ 